\title{
Implementation of an Evidence-Based Practice Discharge Medication Protocol for Heart Failure Patients to Reduce 30-Day Readmissions
}

\author{
Dawn Onstott \\ University of St. Augustine for Health Sciences, d.onstott@usa.edu \\ DOI: https://doi.org/10.46409/sr.QTUR9486
}

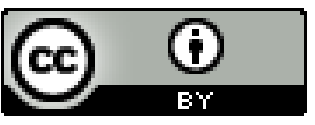

This work is licensed under a Creative Commons Attribution 4.0 License.

Follow this and additional works at: https://soar.usa.edu/scholprojects

Part of the Cardiovascular Diseases Commons, Community Health and Preventive Medicine Commons, and the Public Health and Community Nursing Commons

\section{Recommended Citation}

Onstott, D. (2021). Implementation of an Evidence-Based Practice Discharge Medication Protocol for Heart Failure Patients to Reduce 30-Day Readmissions. [Doctoral project, University of St Augustine for Health Sciences]. SOAR @ USA: Student Scholarly Projects Collection. https://doi.org/10.46409/ sr.QTUR9486

This Scholarly Project is brought to you for free and open access by the Student Research at SOAR @ USA. It has been accepted for inclusion in Student Scholarly Projects by an authorized administrator of SOAR @ USA. For more information, please contact soar@usa.edu, erobinson@usa.edu. 
Implementation of an Evidence-Based Practice Discharge Medication Protocol

for Heart Failure Patients to Reduce 30-Day Readmissions

Dawn Onstott DNP, RN

School of Nursing, University of St. Augustine for Health Sciences

This Manuscript Partially Fulfills the Requirements for the

Doctor of Nursing Practice Program and is Approved by:

Douglas M. Turner PhD, DNP, RN, CNE, NE-BC, NEA-BC

Sheri Jacobson PhD, RN

Debra Stiffler DNP, RN, NE-BC

March 27, 2021 


\begin{abstract}
Practice Problem: An estimated 6.5 million American adults $\geq 20$ years of age have heart failure (HF) and worldwide 1 to $2 \%$ of the total healthcare budget is spent on HF. To improve outcomes and streamline the treatment of HF patients, The American Heart Association (AHA) joined with the American College of Cardiology (ACC) and created the Get With The Guidelines Program (GWTG).
\end{abstract}

PICOT: The PICOT question that guided this project was in adult HF patients admitted to the cardiovascular unit under the care of the hospitalist service, does implementing an evidence-based practice (EBP) discharge medication protocol for physician use based on the AHA GWTG program's HF discharge medication protocol, compared to no standardized discharge protocol, improve patients' 30-day readmission rate, in 12 weeks?

Evidence: Evidence from 10 studies supported implementing an evidence-based GDMT tool into a standardized HF discharge medication protocol for this project.

Intervention: Education and encouragement of use of the AHA GWTG discharge medication protocol for $\mathrm{HF}$ in the electronic health record (EHR) was provided to a group of physicians on a cardiovascular unit. The intervention was over a four-week period and pre- and post-intervention protocol use was observed with specific measures analyzed for observation of improvement.

Outcome: The results determined there was minimal statistical significance, however, there was a decrease in the financial measure of the cost of HF readmissions denoting a clinical significance. Conclusion: Continued use of a guideline-based discharge medication protocol, such as the one utilized in this project, is recommended based on the results and evidence provided in this project. 


\section{Implementation of an Evidence-Based Practice Discharge Medication Protocol for Heart Failure Patients to Reduce 30-Day Readmissions}

Patients are diagnosed every day with heart failure (HF), a prominent form of heart disease. Since HF is a complex syndrome, it requires a multidisciplinary approach to assist in decision-making for each patient's treatment plan. To improve outcomes and streamline the treatment of HF patients, The American Heart Association (AHA) joined with the American College of Cardiology (ACC) and created the Get With The Guidelines Program (AHA, 2018). The program is used by hospitals to improve heart disease patients' care by promoting consistent adherence to the latest scientific treatment guidelines (AHA, 2018). This paper will evaluate the effects of utilizing a guideline-based discharge medication protocol within the patient's electronic medical record (EMR) for the discharging provider.

This evidence-based practice (EBP) change was intended to improve the outcomes for HF patients as an integral part of their comprehensive discharge plan. Utilizing a systems-level approach to affect change in a healthcare organization may translate the knowledge that exists supporting guideline-based HF management into standard discharge practice. Decreasing variation at discharge for HF patients by implementing a standardized discharge protocol has been associated with a better quality of care and decreased readmission rates (Basoor et al., 2013; Smith et al., 2020). Hospitalization is an opportunity to optimize HF therapy because it gives the physician a chance to consult with patients about the importance of adherence to HF medication and of regular monitoring (Cowie et al., 2017). The DNP project's goal is to implement the discharge protocol to reduce 30-day readmission rates for HF-related causes. 


\section{Significance of the Practice Problem}

$\mathrm{HF}$ is a chronic, progressive condition in which the heart muscle cannot pump enough to meet the body's blood and oxygen needs (AHA, 2017). An estimated 6.5 million American adults $\geq 20$ years of age have HF (Benjamin et al., 2018 p. 7). The financial impact is enormous.

Worldwide, 1 to $2 \%$ of the total healthcare budget is spent on HF (Lesyuk et al., 2018, p. 1). It is one of the most frequent causes of hospitalization and accounts for more than $\$ 30$ billion of United States (US) healthcare expenditure annually (Reddy \& Borlaug, 2019).

The early post discharge period is a particularly high risk time that often leads to poor outcomes (Smith et al., 2020). An average of $22.3 \%$ of HF patients are readmitted to the hospital within 30 days at a mean cost of \$14,631 per patient (Kilgore et al., 2017, pp. 65-66). At discharge, patients are often prescribed numerous medications and must make drastic lifestyle changes to improve their HF symptoms and outcomes. Also, there may be multiple comorbidities to be managed alongside the diagnosis of HF (Albert \& Kozinn, 2018).

The Affordable Care Act of 2010 recognized this as an essential issue (Affordable Care Act, 2010). The legislation instituted a program to reduce the readmission rates of conditions such as HF by penalizing providers for higher-than-average readmission rates. HF hospitalization is a severe burden on healthcare, consuming significant healthcare resources, inflicting substantial morbidity and mortality, and critically impacting the patient's quality of life (Cowie et al., 2017; Yancy et al., 2018). It is prudent for healthcare organizations to seek the best options to increase reimbursement for HF patients. These strategies must decrease the high cost for readmission and provide the best outcomes for patients.

In the state of Florida, hospitalizations for $\mathrm{HF}$ among Medicare-eligible persons aged $\geq 65$ years were 38, 347 in 2016 (CDC, 2016). In comparison, over 1,747 people in Duval County, 
Florida, were hospitalized in 2016 due to HF (Florida Department of Health, 2019). The hospital setting for the Doctor of Nurse Practice (DNP) project has identified a significant issue with increased readmissions of HF patients from $26.3 \%$ in 2019 to $28.2 \%$ in the first quarter of 2020 (D. Stiffler, personal communication, May 2020).

Currently, the organization where the EBP occurred has an "A" rating on the national Leapfrog annual survey of healthcare providers (The Leapfrog Group, 2020). An area of improvement identified as "well below the national average" is "communication about medication" (The Leapfrog Group, 2020). Implementing the use of a structured discharge medication protocol such as the AHA HF discharge medication protocol, in the EHR allowed physicians to initiate, add, and adjust medications before discharge. This change was intended to help patients achieve optimal therapy, reduce the chance of costly readmissions, and lead to better quality outcomes. An associated physician-led conversation with patients at discharge about the medication inclusion, combined with nursing's reinforcement of the education at discharge sought to improve the organization's medication scores on the Leapfrog survey.

\section{PICOT Question}

The evidence-based intervention answered the following question: In adult HF patients admitted to the cardiovascular unit under the care of the hospitalist service $(\mathrm{P})$, does implementing an EBP discharge medication protocol for physician use based on the AHA's GWTG program HF discharge medication protocol (I), compared to no standardized discharge protocol $(\mathrm{C})$, improve patients' 30-day readmission rate $(\mathrm{O})$, in twelve weeks $(\mathrm{T})$ ?

The patient population included in the EBP change project were adult inpatients at a forprofit hospital in Jacksonville, Florida, who were diagnosed with HF and admitted to the 
cardiovascular care unit. The patients included were under the medical care of the Team Health Hospitalist group.

HF patients' comprehension of discharge instructions is often inadequate (Regalbuto et al., 2014). HF patients require clear guidance from both the physician and nurse on what medications and instructions to follow when returning home. Providing useful discharge instructions, proper dose up-titration, education about HF monitoring, and strict follow up decreases readmissions for HF (Basoor et al., 2013). A protocol is a system of rules that explain the correct conduct and procedures to be followed in formal situations (Merriam-Webster, 2020). Protocols include guidance based on evidence from novel drug therapies, a treatment algorithm with more care options, an updated approach to prevention, and essential updates regarding various forms of HF and inpatient comorbidities (Fonarow, 2011; Yancy et al., 2018; Zamorano \& Lozano, 2015).

The Center for Medicare and Medicaid Services (CMS, 2020) has developed a Hospital Readmissions Reduction Program (HRRP). This Medicare value-based purchasing program decreases payments to Inpatient Prospective Payment System (IPPS) at hospitals with excessive readmissions (CMS, 2020). IPPS links payment to quality healthcare. Readmission for HF under IPPS is an unplanned readmission within 30 days of discharge from the initial admission for HF, and patients who are readmitted to the same hospital or to another applicable acute care hospital for any reason (CMS, 2020).

\section{Evidence-based Change Model and Change Theory}

System-level practice change must be supported by a coalition of promoters who have decided upon their goal, identified the known predictors of the goal, and aligned the strategies and action steps accordingly to be sustainable (University of Texas, 2018). To form a coalition of reinforcement, a nurse-driven system-level evidence-based change project must connect with a 
need of interest to gain physician involvement and adherence to project initiatives. Utilizing a well-developed and trusted evidence-based change model will make the difference in planning, implementing, and evaluating the project's intention.

The Iowa Model (see Figure 1, Appendix A) is an evidence-based model developed by nurses, for nurses, to assist in incorporating successful strategies learned when undertaking research utilization projects (Iowa Model Collaborative et al., 2017). The Iowa Model was chosen because of its ease of use and focus on organizational-level change. The step-by-step implementation process is clearly outlined. Leaders start by identifying a problem such as increasing readmission rates of HF patients. They then investigate if this problem is a priority of the organization to improve. This was done through confirmation by administrative leadership in a formal letter. The project manager (PM) confirmed organizational interest and formed a team. Stakeholders were identified through collaboration with the PM's preceptor. The team included the PM (student), preceptor, data analyst, hospitalist leader, cardiovascular nurse manager, and former HF clinic nurse practitioner. A search for evidence to support the change process was conducted (see Figure 2, Appendix A). The succeeding process was the designed appearance of the change. The PM synthesized and appraised the evidence for the most beneficial strategy to address the problem. The change was evaluated for appropriateness for the organization. The intervention plan was discussed with the key stakeholders to assess their support of implementation. The project results were presented to all stakeholders to encourage continued support of the protocol usage throughout the organization. Employing a systematic approach to integrating a discharge protocol into the routine of discharging HF patients will make the impact of the EBP outcome on the patients and the health system easier to follow and to assess for necessary changes. The project results were disseminated through a presentation to the key 
stakeholders, submitted to nursing journals for publication, and submitted to present at an EBP nursing conference.

In addition to having an EBP model to follow for the structure of change, a leader should understand change at the organizational level and have a theoretical basis to create a vision of change for all to understand (Titler, 2008). Difficult times in healthcare call for interprofessional collaboration to improve and sustain the best outcomes for safe and high-quality patient care (Wojciechowski et al., 2016).

Lewin's Three-Step Model for Change Management was selected as theoretical support because it is used by nurses for quality improvement projects to transform care (Wojciechowski et al., 2016). Lewin's theory proposed individuals and groups were influenced by restraining forces or obstacles. These were aimed at keeping the status quo. However, Lewin noted driving forces could be used as a positive push to cause change to happen (Lewin, 1951).

The three steps of the model were unfreezing, change, and refreezing (Lewin, 1951). The discharge protocol implemented aimed to change the providers' previous discharge process of orders for HF patients. Engaging medical practitioners to "unfreeze" their current practice requires strong influence and teamwork. These efforts may lessen the anxiety of the unknown to diminish the restraining forces. Involving the nursing team and leadership to "drive" the change and support the EBP project was intended to lead to the project's desired results. Finally, a "refreezing" of the new norm can continue to benefit the healthcare teams' professional practice, improve patient health, and maximize future organizational outcomes for HF readmission rates.

\section{Evidence Search Strategy}

The search strategy used the University of St. Augustine (USA) Library's databases: CINAHL Complete, PubMed, Elsevier, ScienceDirect, Academic Search Index, and Pub Med. 
Reference indexing was also used to find reputable sources for support. The keywords used in the USA search were "heart failure" and "guidelines" in the title and "readmission" in the subject heading. The criteria peer-reviewed, English language, and publishing dates between 2010 and 2020 were used to refine the search. Inclusion criteria were: articles that utilized the GWTG quality improvement program and those that used a checklist, protocol, or guideline-directed therapy to reduce readmissions. Exclusion criteria removed articles that did not directly correlate to the interventions, did not show evidence of reduced readmissions, or were duplicates. In the search through PubMed, the MeSH headings used were "patient readmission," "patient readmission/statistics," "numerical data," "heart failure," and "guidelines." The dates searched were 2010-2020, and the same inclusion and exclusion criteria were applied. The reference lists of studies included and systematic reviews identified in the search were carefully examined for further eligible studies (see Figure 2, Appendix A).

\section{Evidence Search Results and Evaluation}

Studies concerning the successful implementation of a HF discharge protocol to reduce readmissions proved to be challenging to obtain. Only 24 articles were found to support this EBP project.

The rationale for inclusion was documented evidence of an improvement in HF patients' readmission or of other outcomes based on similar interventions. Guideline-directed therapy and protocols were also included as the proposed project's intent is to utilize direction from the GWTG discharge protocol (see Figure 3, Appendix A). The results included studies that needed to be generalizable to other HF discharge interventions, and medication optimization was a primary factor to be considered. Articles were excluded if they did not involve HF patients that were hospitalized and/or readmission outcomes. 
In the 10 articles selected and appraised, the overall level of evidence, based on the Johns Hopkins Nursing Evidence-Based Practice Model and Guidelines (Dang \& Dearholt, 2017), was mostly Level II, then Level III, with one Level I (see Figure 1, Appendix B). The quality grade of eight of the articles was a B, which is interpreted as good, reasonably consistent results, adequate sample size and control, and relatively decisive conclusions. Two of the articles were found to be a quality grade $\mathrm{A}$, indicating the highest level of quality. The search strategy was limited due to the availability of studies focused on reducing the readmission rate of HF patients by specifically using a guideline-directed discharge protocol. Articles that did not have at least a quality grade of B were not considered for inclusion. Four articles demonstrated Level III evidence, which can be understood as having a well-designed study without randomization. Five articles were Level II, and one article was a Level I. These criteria were felt to indicate the potential for positive results if the project was accepted (see Appendix C).

\section{Themes from the Evidence}

The articles included as evidence for this project were born from studies completed in various hospital settings and with many sample sizes. Participant hospitals in the studies may have been enrolled in the GWTG-HF program or in a different guideline-directed HF management program. Surveys, observational studies, core measure comparison, implementation studies, and retrospective studies were some of the methods used to obtain data on HF patient outcomes.

Themes from the evidence were examined as they directly related to the PICOT question (see Appendix D). The most prevalent theme from the literature was the high level of variability in how patients with HF have been prescribed treatment during their hospital stay and at discharge (Basoor et al., 2013; Cutshall et al., 2018; Deschaseaux et al., 2016; Gilstrap et al., 2018; 
Heidenreich et al., 2014; Kociol et al., 2012; Yamaguchi et al., 2018). Discharge checklists were used by some facilities (Basoor et al., 2013; Kociol et al., 2012) to enhance the healthcare team's ability to prescribe and order medications and to minimize the opportunity for missed guideline recommendations. Medications commonly used as the standard treatment for patients with HF with reduced ejection fraction (HFrEF) were beta-blockers (BB), neurohormonal agents, and diuretics (Heidenreich et al., 2014; Wang et al., 2011; Yamaguchi et al., 2018). Some studies found these medications were inconsistently prescribed (Cutshall et al., 2018; Gilstrap et al., 2018; Heidenreich et al., 2014), not prescribed at all (Cutshall et al., 2018; Deschaseaux et al., 2016; Gilstrap et al., 2018), and lacked the up-titration suggested by most HF guidelines (Basoor et al., 2013). The patient population was determined to be at risk for hypotension due to the BB's, angiotensin converting enzyme inhibitors (ACE), or angiotensin II receptor blockers (ARB) commonly prescribed for HF (Gilstrap et al., 2018). The risk could have contributed to the hesitancy of patient adherence and of physician prescription in the studies. The irregular prescribing practice may be related to the lack of substantial evidence, indicating a need for guideline-directed medical therapy (GDMT) protocols to be implemented to assist in reducing HF readmission rates.

Reducing readmission rates is a leading driver for healthcare organizations to employ actions that help HF patients. Achieving the recommended $<20 \%$ readmission rate directed by most HF management programs has proven to be difficult (Bergethon et al., 2016). The studies reviewed reinforced how problematic it was to prevent HF patients from demonstrating worsening symptoms, which led to hospital readmissions (Cutshall et al., 2018; Gilstrap et al., 2018; Kociol et al., 2012; Yamaguchi et al., 2018). Approximately 1 million hospitalizations a year are related to HF (Deschaseaux et al., 2016). Demonstrating lower readmission rates for the 
HF patient population can lead to higher reimbursement rates and lower quality scoring for hospitals (Gilstrap et al., 2018). The Basoor et al. (2013) study with the highest level of quality evidence reported a significant reduction in 30-day and 6-month readmissions due to implementing a guideline-directed discharge checklist similar to the protocol implemented in this project. Other studies that focused on discharge intervention and GDMT did mention a decrease in readmission rates as an indicator of accomplishment (Bergethon et al., 2016; Kociol et al., 2012).

The literature review supported further investigation of quality improvement and systemslevel change initiatives utilizing evidence-based practices (Basoor et al., 2013; Deschaseaux et al., 2016; Fonarow, 2011; Heidenreich et al., 2014; Kociol et al., 2012). Available evidence has been synthesized to demonstrate the potential of an EBP change to reduce readmissions of HF patients. This evidence supported implementing a discharge protocol using AHA's GWTG recommendations at discharge.

\section{Practice Recommendations}

Rather than relying on physician preference and level of HF diagnosis, HF patient treatments should be individualized based on their specific needs and aligned with proven therapies to reduce symptoms (Basoor et al., 2013; Bergethon et al., 2016; Cutshall et al., 2018; Deschaseaux et al., 2016; Gilstrap et al., 2018; Heidenreich et al., 2014; Kociol et al., 2012; Yamaguchi et al., 2018). The evidence supported a need to address the reduction of HF readmissions in a systematic way. This was accomplished by implementing a discharge protocol to standardize and guide physicians treatments based on evidence-based guidelines from AHA recommendations (Basoor et al., 2013; Bergethon et al., 2016; Cutshall et al., 2018; Deschaseaux et al., 2016; Fonarow, 2011; Gilstrap et al., 2018; Heidenreich et al., 2014; Kociol et al., 2012; 
Wang et al., 2011; Yamaguchi et al., 2018). It is common for HF patients to have comorbidities, such as high blood pressure, renal disease, diabetes, and noncompliance issues. Gilstrap et al. (2018) reported with Level II evidence the application of guidelines recommended for stable HF populations was increasingly limited for hospitalized patients by hypotension, renal dysfunction, and inotrope use, causing clinicians to frequently deviate from guideline use.

Three good to high-quality studies with Level I and Level II evidence reported an association between GDMT with reduced readmissions (Basoor et al., 2013; Bergethon et al., 2016; Kociol et al., 2012). However, Cutshall et al. (2018) indicated an increased length of stay among the GDMT patients, which indirectly supported the DNP project. Five studies identified as having good quality with Level II and Level III evidence identified a lack of consistent GDMT among the HF inpatient population (Cutshall et al., 2018; Deschaseaux et al., 2016; Gilstrap et al., 2018; Kociol et al., 2012; Yamaguchi et al., 2018). To change healthcare provider practice and create a streamlined HF discharge plan, implementation strategies must be coupled with novel guideline dissemination and organized physician engagement strategies such as the ones found in the literature (Ellrodt et al., 2013).

Increases in all quality measures were observed over time among patients in settings that consistently used the GWTG protocol. (Heidenreich et al., 2014; Kociol et al., 2012). Yamaguchi et al. (2018) categorized participants into three groups and compared their 1-year mortality rate. The results were: prescribed both an ACE-I/ARB (7.8\%), either an ACE-I/ARB (19.6\%), and neither (34.4\%). A study by Basoor et al. (2013) documenting checklist utilization was appraised as having the highest level of evidence and highest quality grade. It supported the use of a standardized discharge protocol, which reduced 30-day readmission rates from $20 \%$ to $2 \%$. 
Strong evidence from the studies supported the feasibility of implementing an established evidence-based GDMT tool (such as the AHA GWTG-HF discharge protocol) into a standardized HF discharge medication protocol. The review further reinforced a need for urgent action to reduce guideline nonadherence for this at-risk patient population. The GWTG discharge medication protocol aimed to improve care quality while decreasing costs. Examples include length of stay, readmissions, negative patient outcomes (Ellrodt et al., 2013; Fonarow et al., 2012; Kociol et al., 2012; Yamaguchi et al., 2018).

\section{Project Setting}

The chosen facility for the project is part of an extensive for-profit healthcare system with 21 hospitals across the country and one in the United Kingdom. The hospital resides in an urban setting with 454-bed capacity. It is competing with other sizeable acute care healthcare organizations to be the leading healthcare provider in northeastern Florida and in its hospital system division. The hospital's mission mentions above all else, the organization is committed to the care and improvement of human life. This organization's vision is to be an excellent place for employees to work and an excellent place for physicians to practice medicine, resulting in an excellent place for patients to receive care. The leadership is dedicated to finding innovative ways to meet their community's healthcare needs, and both employees and leadership have a shared vision to reach the highest levels of quality care.

The community served commands attention to $\mathrm{HF}$, as it is an increasing issue for the population (Florida Department of Health, 2018). The rise of HF 30-day readmissions from $26.3 \%$ in 2019 to $28.2 \%$ in the first quarter of 2020 is not easily explained by patient demographics or behaviors but does offer an urgency to act (D. Stiffler, personal communication, May 2020). 
The institution's organizational structure consists of an executive team under the authority of the board of trustees. Despite being a small part of an extensive healthcare system, this hospital has a strong sense of community and dedication of its staff to delivering a quality healthcare product. The stakeholders in this hospital that have partnered with the PM were crucial to the success and sustainability of the intervention (see Table 1 p.15).

Table 1.

Key Stakeholders

\begin{tabular}{l|l}
\hline \multicolumn{1}{c|}{ Name } & \multicolumn{1}{c}{ Position } \\
\hline Debra Stiffler & Chief Nursing Officer \\
\hline Mary Reval & Facility Medical Director Hospital Service Department of Medicine Chairman \\
& Memorial Hospital Team Health \\
\hline David Siebert & Chief Financial Officer \\
\hline Kevin McKeown & Chief Medical Officer \\
\hline Albert Holt IV & Director of Clinical Informatics \\
\hline Luciana Swiridowsky & Manager of Cardiovascular Unit \\
\hline Nancy Fiest & Former HF Clinic Nurse Practitioner \\
\hline Michael Bristow &
\end{tabular}

Support of the project was confirmed by a written agreement between the PM, preceptor, and the Facility Medical Director of Hospital Services Department before implementation, and approval for continued sustainability has been established by leadership and the medical team since results have been shared. Sustainability was encouraged through the future use of a systemwide HF discharge protocol for practitioners. Compliance is intended to be enforced by the cardiovascular and hospitalist leaders. The charge nurse on the cardiovascular unit where the project was implemented is to continue recommending the discharge protocol upon daily rounding with the physicians when a patient is identified as having a diagnosis of HF.

The level of interprofessional collaboration for this project was high. It required a physician's commitment to participate, administrative-level approval, informatics support, nursing 
guidance and recognition, and financial backing to take each team member's time away from current initiatives. This collaborative effort allowed participants to achieve together more than they can individually, to serve a larger group of people, and to grow at individual and organizational levels through systematic evidence-based change (Green \& Johnson, 2015).

Strengths, opportunities, weaknesses, and threats were identified that may have affected the project's planning, implementation, and execution phases (see Appendix F). The biggest obstacle identified that the project faced was practitioner resistance to change due to high patient volume and stressful working conditions exacerbated by the Covid-19 pandemic. The organization was focused on staffing for optimal support of high-risk patients and on preventing the spread of COVID-19. The intentions for the project were to highlight the need to address the worsening issue of HF patient outcomes and take action with a proactive, evidence-based plan.

\section{Project Overview}

The DNP project's mission was "To provide HF patients a considerate, evidence-based discharge medication regimen to reduce their chance of 30-day readmission". The DNP project's vision was "Purposeful reduction in HF patient complications through collaborative, guidelinebased efforts in patient care excellence." These statements directly align with the organization's mission and vision as the patient is the focus for improvement.

The project's short-term objective was to implement a HF discharge protocol in the hospital's cardiovascular unit. The long-term objective was to employ the continued use of a sustainable system-wide HF discharge protocol to reduce 30-day HF readmissions. The risk of such an ambitious goal is that HF patients are known for their multiple comorbidities and noncompliance due to strict medication regimens, diet, and self-monitoring (Sevinc \& Samancioglu, 2017). 
The risk for unintended consequences was addressed by educating the Hospitalist's group prior to implementation that complicated HF patients' discharge medication should be scrutinized based on laboratory values identified in the GWTG-HF protocol and documented if contraindications existed. If questions arise, then a conversation with the consulting cardiologist was recommended per AHA guidelines.

\section{Project Plan (Method)}

A nurse's ability to turn evidence into practice can be difficult if they have not mastered obtaining and appraising evidence. The Iowa Model (see Appendix A, Figure 1) guides clinical decision-making for healthcare professionals and the EBP process from both the clinician and systems perspectives (Iowa Model Collaborative et al., 2017). This model was chosen for this project because of its ease of use and focus on organizational-level change. The Iowa Model also offered a heuristic process for the investigator to gain a greater understanding of what kind of change agent they may be in their future leadership role. The model's use of a systematic approach was helpful to this particular project as it was essential to determine the project's impact on the patients' health and the system's outcomes. The following section is an outline of how the model guided the EBP project.

\section{Step 1: Identify Triggering Issues/Opportunities}

The PM identified a need to address the increasing 30-day readmission rate for HF patients at the specific facility. The issue of increasing HF readmissions at this specific facility was highlighted in a quality measures report and shared with the division. Efforts have been made to improve HF patient outcomes but have yet to produce positive results in this population. According to Suter et al. (2014), 30-day readmissions are costly to healthcare organizations and are likely to occur in one out of every four patients (p. 1333). 


\section{Step 2: State the Question or Purpose}

The project aimed to determine if "In HF patients, does implementing an EBP discharge medication protocol for physician use, compared to no standardized discharge medication protocol, improve patients' 30 -day readmission rate, in twelve weeks?”.

\section{Step 3: Form a Team}

The individuals identified as team members are not identical to the list of key stakeholders. The selection of team members requires consideration of interprofessional involvement, and of the skill sets required to plan, conduct, and evaluate the project (Iowa Model Collaborative et al., 2017). The project's active phases of planning, implementation, evaluation, and dissemination required a diverse set of skill sets and engagement in improving HF patients' outcomes.

The PM has over 10 years of nursing leadership experience. The PM has worked with many of the stakeholders for over 2 years and has established trust. The team was formed to include the PM, preceptor, and data analyst.

\section{Step 4: Assemble, Appraise and Synthesize Body of Evidence}

It is imperative to appraise the entire body of evidence to gain sufficient knowledge of potential barriers and successes (Dang \& Dearholt, 2017). The John Hopkins Nursing EvidenceBased Practice Guidelines has assisted this phase (see Figure 1 Appendix B).

\section{Step 5: Is there Sufficient Evidence?}

This step can be seen as both subjective and objective depending upon the evaluator.

Weighing of the evidence involves incorporating multiple types of evidence as part of the initial evidence review, evaluating evidence quality, quantity, and consistency (Iowa Model Collaborative et al., 2017). There is sufficient supportive evidence for utilizing AHA's GWTG HF 
protocol in reducing 30-day readmission rates (Bergethon et al., 2016; Kociol et al., 2012; Wang et al., 2011). There is high-quality evidence backing the GDMT in reducing 30-day readmission rates and outcomes for HF patients (Basoor et al., 2013; Fonarow et al., 2012). There is abundant evidence highlighting the need for consistent GDMT at discharge for HF patients (Cutshall et al., 2018; Deschaseaux et al., 2016; Fonarow et al., 2012; Gilstrap et al., 2018; Heidenreich et al., 2014; Wang et al., 2011). The PICOT question was supported by the evidence.

\section{Step 6: Design the Practice Change}

An interview with the key stakeholders about the plausibility and support for the initiative provided insight into the project design. A practice change was created that did not lead to staff rebellion. Organizational infrastructure and the commitment of resources was assessed throughout the project. It was important to identify all the possible gaps that needed to be filled before implementation (Iowa Model Collaborative et al., 2017).

\section{Step 7: Is Change Appropriate for Adoption in Practice?}

The judgment of whether or not the project was appropriate for practice was dependent on many factors including the results of the statistical analyses, clinical significance, and the practice change's effect on the unit's culture. A consistent feedback loop between the PM, physicians, data analyst, and key stakeholders was enforced. The results of the project were summarized and disseminated to select members of the organization for a potential future system-wide implementation.

\section{Step 8: Integrate and Sustain the Practice Change}

The integration of change requires ongoing engagement of the team members after the project is completed with continuous evaluation of key performance indicators. In this project, the Hospitalist Group buy-in was significant to the results of the practice change. The charge nurse on 
the cardiovascular unit was encouraged to educate and remind the rounding practitioner to use the discharge protocol. A continuance of use of the protocol was recommended, and practitioners were educated on its benefits and use requirements.

\section{Step 9: Disseminate the Results}

Results were disseminated to key stakeholders and team members. The information presented to key stakeholders was in a formal format at the Executive Cardiovascular Committee meeting and sent in a Power Point presentation to all key stakeholders. The project manager will pursue publication for this project.

The planning, initial data collection, and submission for approval was completed within four weeks of the project's implementation and the remainder of the data collection occurring throughout the implementation phase and 30 days post to capture any readmissions (see Table A1). Analysis and measurement of data was necessary after the last phase and continued until interpretation of the results were clear.

The project budget included the cost of wages for the utilization of team members' time to assist in the collection and organization of data. The discharge protocol was embedded in the organization's EHR, so there was no cost for customization of the EHR. There was minimal cost to the organization (see Table A3).

The timeline of the project was broken into three phases and extends from identification of the practice problem until dissemination of the evidence. The first phase was where the problem was identified, the organization was evaluated for readiness for an EBP change project, evidence was found to support an EBP change, and a plan was created for the project. The second phase consisted of organizational approval for the intended EBP change, IRB approval, stakeholder engagement, and implementation. The PM used a 4-week timeframe for implementation. The 
final phase included data collection, data evaluation, evaluation of plan for sustainability, and dissemination of the findings. All three phases concluded April of 2021. (see Appendix E).

\section{Results}

The following section describes the data collection, evaluation, analysis, and the interpretation for significance.

\section{Data Collection and Analysis}

Data collection and review occurred retrospectively for 4 weeks prior to and 4 weeks after implementation of the AHA GWTG-HF protocol; 30-day readmission rates were assessed post intervention. Baseline measurements were collected using chart audits of all HF diagnosed patients in the cardiovascular unit under the Team Health hospitalists' care and were compared to data collected throughout the implementation phase. All HF admissions were documented 30days post-intervention to capture patient readmissions. In all project phases, data were collected to evaluate the outcomes of improvement in the 30-day readmission HF patient readmission rate and protocol usage (see Table A1). Necessary data was transferred to an Intellectus software spreadsheet for analysis (see Table A2).

\section{Recruitment, Selection of Participants and Approvals}

Inclusion criteria were specific to project dates and included adult patients between 18 and 100 years of age, similar to AHA GWTG HF guideline inclusion criteria. Patients were included if they were admitted to the cardiovascular unit, under the Team Health hospitalist care, and had a HF diagnosis. Patients were excluded if they were upgraded to another unit, discharged by a physician other than a hospitalist, admitted to hospice service, or deceased. The medical record number identified the patients. No personal identification information was collected. 
The approval process for the USAHS Evidence-based Practice Review Council (EPRC) included submitting endorsements received from the facility where the project was to be implemented and authorization of use for the Iowa Model and the AHA-GWTG discharge protocol. The Team Health Hospitalist leader and the Cardiovascular Service Line Administrator gave written project approval.

\section{Participants in Data Collection and Analysis}

The PM collected patient information from the EHR. The analyst responsible for entering data into other cardiac registries collected specific daily reports from the quality department. The reports identified all patients admitted and coded with a diagnosis of HF in the specified date range. Reports were provided to the PM weekly.

\section{Data Storage and Misplacement}

Spreadsheet programs are valuable tools for entering, organizing, and storing data (Broman \& Woo, 2018). Non-specific patient data was stored in the PM's personal computer within an Excel spreadsheet and Intellectus software. The PM was the only team member with access to the data to ensure process integrity. Daily patient reports were returned to the analyst after data extraction for disposal. The PM reviewed all patients admitted during the implementation phase to ensure no HF patients were omitted. No missing data was found.

\section{Integrity of the Data}

The PM validated data integrity of daily reports weekly by applying current methods to identify HF hospital patients through the Meditech EHR.

\section{Evaluation Design, Tools, and Type of Data}

The project used a pre- and post-design to evaluate the impact of the intervention (Stratton, 2019). Primary data examined included a mixture of continuous and discrete variables 
presented as standard deviations, frequencies, means, and percentages (Giuliano \& Polanowicz, 2008). Descriptive data were nominal, ordinal, and continuous (Marshall \& Jonker, 2010). Variables were analyzed using descriptive, comparison, and non-parametric statistics.

\section{Categories of Measure}

The outcome measure was the 30-day readmission rate for HF patients both pre, post, and for 30 days after the end of the implementation phase (Stratton, 2019). Balancing, process, financial, and sustainability measures were analyzed. Benchmarks were recorded based on preintervention data (see Appendix G).

\section{Data Analysis}

Descriptive statistics, paired t-tests, and chi-square tests were used to analyze the data (Vetter \& Mascha, 2018). "N" indicated the patient was not readmitted and "Y" indicated the patient was readmitted (see Appendix H, Table 1). Results of the Chi-square test were not statistically significant based on an alpha value of $0.05, \chi 2(2)=1.11, p=0.573$. These suggested the primary outcome measure (30-day readmission) and phase were independent of one another (Intellectus Statistics, 2019). This further implied the observed frequencies were not significantly different than the anticipated frequencies. None of the data in the 30-day intervals met the target of at least a 20 percent reduction of the 30-day readmission rate (see Table H2)

The process measure of HF discharge protocol utilization was analyzed using a two-tailed paired samples t-test (Intellectus Statistics, 2019). The result was statistically significant based on an alpha value of $0.05, \mathrm{t}(12)=-6.68, \mathrm{p}<.001$, indicating the null hypothesis could be rejected (see Appendix H, Table 3 and Figure 1). Descriptive analysis of the number of times the protocol was used indicated an average of $1.46(\mathrm{SD}=1.71, \mathrm{SEM}=0.48, \mathrm{Min}=0.00, \mathrm{Max}=6.00$, 
Skewness $=1.41$, Kurtosis $=1.75)$. The target of $95 \%$ usage in each week was never reached (see Table H4).

An insufficient number of observations was identified when performing descriptive statistics on the balancing measure of number of HF patients identified. Frequencies and percentages were calculated (Intellectus Statistics, 2019). "N" indicated the protocol was not mentioned to the rounding physician, and "Y" indicated the protocol was mentioned (see Table H5). No data was collected during the fifth 2-week period as it was post-intervention assessment time.

The financial measure was analyzed using the mean cost of readmission per patient of $\$ 14,631$ (see Table H6). These percentage reductions surpassed the target of $20 \%$ per 30 -day period. Sustainability of the use of the protocol 30-days after the intervention period (Trimester 3) was measured using frequencies and percentages. "N" represented the protocol not being used (see Figure H2). The target goal of at least $95 \%$ usage was not met.

\section{Statistical and Clinically Significant Results}

The only test that produced a statistically significant result was the two-tailed paired samples t-test for the process measure (Intellectus Statistics, 2019). This indicated the null hypothesis could be rejected. The outcome of the $\mathrm{p}$ value must be less than $5 \%$ for the intervention to be deemed statistically significant (Andrade, 2019). The p value was $>0.001$.

Considering the small sample size in the last two phases, clinical significance can be partially assumed. With reminders to physicians, there was a $40 \%$ increase in use of the protocol. This indicated the importance of communication between the nurse and physician to improve HF management at discharge. Unfortunately, after the intervention phase, there was a $37 \%$ decrease in protocol usage. The 30 -day readmission rate did not meet the goal of a $20 \%$ reduction from the 
benchmark measure; however, it did result in a $10 \%$ reduction comparing pre-intervention 30-day readmission rates to the last 30 days observed. Overall, this can be seen as an improvement in the outcome measure.

The most obvious clinically significant finding was the financial measure. The decrease in cost of readmissions for each 90 -day period was $30 \%$ and $29 \%$ respectively, which exceeded the project's goal of $20 \%$ decrease. This may represent an attractive amount of savings for the hospital and support continued protocol use.

\section{Formative and Summative Criteria}

The GWTG registry collects achievement and quality data from organizations that participate in their program (AHA, 2020). This includes, but is not limited to, prescribing of ACE, $\mathrm{ARB}$, aldosterone antagonist (AA), and evidence-based specific $\mathrm{BB}$ at discharge. The PM collected these formative results in the pre- and post-intervention phases and will share the data with key stakeholders. Summative criteria were results of benchmarking measures.

\section{Extraneous Variables}

The PM controlled for extraneous variables by using only a single inpatient unit, patients discharged from the hospitalist group, and data needed for evaluation. This reduced the number of participants for data collection.

\section{Protection of Human Subjects}

Patient data were not collected until approval was received from the EPRC of USAHS. This ensured the ethical safety of the project. The hospital where the project was implemented did not have an IRB. 


\section{Impact}

HF is a problem not easily solved. The facility previously identified the value of the evidence-based medication guidelines by having the recommended protocol medications embedded into each patient discharge summary. This made a smooth transition for the PM to reinforce its use. Hardwiring a new practice for this facility's Team Health Hospitalists group was not as smooth.

Before the project, the PM identified through data collection that usage of the existing tool was minimal (see Table H4). Her efforts to encourage protocol usage were not impactful enough sustain increased use of the HF protocol. Physician noncompliance during the intervention phase was discussed with their leadership. After formal presentation of results, there was discussion amongst the medical team that supported future protocol use.

Review of the 30-day readmission rate indicated no statistically significant difference associated with the intervention. However, there was a decrease in the actual readmission rate from pre to post intervention (see Table H1). Reducing hospital readmissions for HF patients is a national priority, and quality improvement efforts are targeting reductions of $\geq 20 \%$ (Bergethon et al., 2016). This project documented a trend of high HF patient readmission rates at this facility. None of the project phases ever reached a 30-day readmission rate lower than $26 \%$ (see Table H1). However, the literature supported that consistent use of the discharge medication protocol will lead to a decreased 30-day readmission rates in HF (Basoor et al., 2013; Kociol et al., 2012).

\section{Future Implications}

The reduction in the readmission cost to the facility between each 30-day period was never less than 29\% (see Table H6), and this represented a significant savings for the hospital. If 
the HF discharge medication protocol occurred at the enterprise-level, then the cost savings would be substantial.

The PM's preceptor stated since the conclusion of the EBP project that the organization is beginning to present a quality improvement initiative on the selection of the AHA-GWTG HF medications that directly relates to reimbursement objectives. Upon discharge, HF patients must have each one of the categories of medication (ACE/ARB/ARNI, BB, and AA) selected by physicians, which aligns with this project's specific goals. Combining reimbursement reduction with an organizational drive for guideline adherence will assist in optimizing the reduction of 30day readmission rates for HF patients. The presentation of this project's results reminded the stakeholders of the evidence supporting the intervention and provided a potential structure for strategic efforts to improve HF patient outcomes.

\section{Limitations}

Limitations that occurred during the EBP project are as follows: First, there was a limited area of surveillance (1 inpatient unit). Had the project involved several units, or the entire population of HF patients, the number of observations would have been more significant. The facility may consider employing the recommended practice change to all HF patient discharges to evaluate for a more significant reduction in readmissions.

Secondly, the time of the project's intervention was interrupted by a global pandemic of COVID-19. The priority of the hospital administration and staff revolved around controlling the spread of infection due to COVID-19, and caring for those affected with the illness. New initiatives were secondary to managing this novel virus with an already limited supply of staffing. Recently, the numbers of hospitalized patients with COVID-19 have decreased and the facility is back to focusing on other priorities. Since dissemination of results, the continuation of GDMT 
with the GWTG-HF discharge protocol may become an organizational focus leading to sustainability of the change. Support for this continued initiative is relevant due to GDMT for HF becoming a recent topic of discussion in recent cardiovascular committee meetings.

Thirdly, the evidence of poor utilization of GDMT by the facility physicians prior to the initiation of the change represents another limitation. A history of inadequate adherence to practice standards with limited oversight and accountability is contradictory to a sustainable practice change. This is an issue leadership may address as the results of this project represent a failure of compliance with recommended guidelines and insubordination. Further study of physician engagement in protocol utilization is needed to identify if a statistical significance truly exists between the protocol and the 30-day readmission rate.

The holiday season being concurrent with the implementation phase may have affected the results. Difficulty adhering to a restricted diet during the holidays and not wanting to be in the hospital during the holiday season may be related to the results. The high readmission rate that continued throughout the project phases may have been due to the "holiday effect" some HF patients experience (Reedman et al., 2008).

Finally, the PM not being employed where the project was implemented was found to be a significant limitation. If the PM worked at the facility there would have been daily observance and encouragement of the protocol with both the physicians and nursing staff. Established relationships can assist in buy-in and a deeper engagement of stakeholders (Rycroft-Malone et al., 2016).

The limitations identified may have affected the statistical significance of the project results but did not affect the importance of the practice problem of HF readmissions. The project has highlighted the availability of a tool within their EHR that discharging practitioners can use to 
better manage HF patient outcomes while not drastically altering their current practice.

Discharging a HF patient can be standardized with this GDMT, with the exception of individual identified exclusionary criteria.

\section{Plans for Dissemination}

The results of this evidence-based practice change project will be shared both internally and externally of the organization. All team members will receive a presentation with PowerPoint slides emailed to them. The Cardiovascular Executive Committee was presented with a face-toface explanation and presentation of results at the March meeting, facilitated by the PM's preceptor. This internal dissemination will be done to enhance awareness, create a clear understanding of the intervention's benefits to the organization, identify areas of improvement in addressing the practice problem, and help motivate the organization to sustain the EBP change.

The external dissemination of results will be sought through two nursing publications, one supported by the American Nurses Association (ANA) and the other supported by the AHA. First, the Online Journal of Issues in Nursing (OJIN) is described as "an online publication that reaches nursing professionals around the world" (American Nurses Association, 2020 ). This monthly, peer-reviewed journal, enhances comprehensive knowledge of topics relevant to nursing and helps build up a shared knowledge base (American Nurses Association, n.d.).

The second nursing publication that will be considered for submission is the American Journal of Nursing (AJN). The AJN reaches more nurses than any other nursing journal through powerful print, website, institution, and social media channels (Lippincott Williams \& Wilkins.org, 2020). It is viewed in Ovid, the institutional platform used by health systems and libraries. This is significant because all healthcare personnel can have access to the information provided by the project. 
This scholarly work will also be submitted to The University of St. Augustine's institutional repository called SOAR@USA. This is an opportunity for the project manager to display the completed work to the public alongside other works from the university's students, faculty and alumni.

The opportunity to present at conferences will be sought at the state and national level. Locally, the Florida Nurses Association hosts an annual Nursing Research and EBP Conference that would be the appropriate forum for the dissemination of findings. On a national scale, the American Nurses Credentialing Center hosts a virtual summit. This includes nurses from around the country who are provided the forum to present their work via the internet to empower professionalism and continued knowledge growth without having to travel. The flexibility and convenience of this virtual option allows for a broader audience to be reached while adhering to the current social distancing requirements.

\section{Conclusion}

HF's burden affects healthcare organizations on many levels. The impetus for this EBP change project is the failure of the organizational efforts to reduce 30-day readmission rates for their HF patient population. Conformity with quality measures such as the AHA's GWTH-HF discharge medication protocol has shown improvements with clinical outcomes (Fonarow, 2011). The problem has been identified and sufficient evidence has been found to support the intervention planned. Organizational readiness will be further assessed to establish a supportive environment for the systems-based EBP change. Forming a team of motivated system-wide interdisciplinary professionals will be essential. Standardization of HF patient discharge medications using a guideline-directed protocol, as detailed in the steps of this project, can be the needed change to address the costly cycle of a HF patients' disease in all healthcare organizations. 


\section{References}

Affordable Care Act., $42 \S 18031$ (2010). https://www.hhs.gov/sites/default/files/ppacacon.pdf

Albert, N. M., \& Kozinn, M. J. (2018). In-hospital initiation of guideline-directed heart failure pharmacotherapy to improve long-term patient adherence and outcomes. Critical Care Nurse, 38(5), 16-24. https://doi.org/10.4037/ccn2018669

American Heart Association. (2017). What is heart failure? https://www.heart.org/en/healthtopics/heart-failure/what-is-heart-failure

American Heart Association. (2018). Get with the guidelines: Heart failure overview. https://www.heart.org/en/professional/quality-improvement/get-with-the-guidelines/getwith-the-guidelines-heart-failure/get-with-the-guidelines-heart-failure-overview

American Nurses Association. (2020). About OJIN.

http://ojin.nursingworld.org/MainMenuCategories/ANAMarketplace/ANAPeriodicals/OJI N/FunctionalMenu/AboutOJIN.aspx

American Nurses Association. (n.d.). ANA Journals.

https://www.nursingworld.org/membership/ana-periodicals/

Basoor, A., Doshi, N. C., Cotant, J. F., Saleh, T., Todorov, M., Choksi, N., Patel, K. C., DeGregorio, M., Mehta, R. H., \& Halabi, A. R. (2013). Decreased readmissions and improved quality of care with the use of an inexpensive checklist in heart failure. Congestive Heart Failure, 19(4), 200-206. https://doi.org/10.1111/chf.12031

Benjamin, E. J., Virani, S. S., Callaway, C. W., Chamberlain, A. M., Chang, A. R., Cheng, S., Chiuve, S. E., Cushman, M., Delling, F. N., Deo, R., de Ferranti, S. D., Ferguson, J. F., Fornage, M., Gillespie, C., Isasi, C. R., Jiménez, M. C., Jordan, L. C., Judd, S. E., Lackland, D., ... Muntner, P. (2018). Heart disease and stroke statistics-2018 update: A 
report from the American Heart Association. Circulation, 137(12). https://doi.org/10.1161/CIR.0000000000000558

Bergethon, K. E., Ju, C., DeVore, A. D., Hardy, N. C., Fonarow, G. C., Yancy, C. W., Heidenreich, P. A., Bhatt, D. L., Peterson, E. D., \& Hernandez, A. F. (2016). Trends in 30-Day readmission rates for patients hospitalized with heart failure: Findings from the Get With The Guidelines-Heart failure registry. Circulation: Heart Failure, 9(6). https://doi.org/10.1161/CIRCHEARTFAILURE.115.002594

CDC.gov. (2016). Chronic disease indicators (CDI). National Center for Chronic Disease Prevention and Health Promotion, Division of Population Health. https://nccd.cdc.gov/cdi.

Center for Medicare and Medicaid Services. (2020). Hospital readmissions reduction program. CMS.Gov. https://www.cms.gov/Medicare/Quality-Initiatives-Patient-AssessmentInstruments/Value-Based-Programs/HRRP/Hospital-Readmission-Reduction-Program

Cowie, M. R., Lopatin, Y. M., Saldarriaga, C., Fonseca, C., Sim, D., Magaña, J. A., Albuquerque, D., Trivi, M., Moncada, G., González Castillo, B. A., Sánchez, M. O. S., \& Chung, E. (2017). The Optimize Heart Failure Care Program: Initial lessons from global implementation. International Journal of Cardiology, 236, 340-344. https://doi.org/10.1016/j.ijcard.2017.02.033

Cutshall, B. T., Duhart, B. T., Saikumar, J., Samarin, M., Hutchison, L., \& Hudson, J. Q. (2018). Assessing guideline-directed medication therapy for heart failure in end-stage renal disease. The American Journal of the Medical Sciences, 355(3), 247-251. https://doi.org/10.1016/j.amjms.2017.11.008

Dang, D., \& Dearholt, S. (2017). Johns Hopkins nursing evidence-based practice: Model and guidelines. (3rd ed.). Sigma Theta Tau International. 
Deschaseaux, C., McSharry, M., Hudson, E., Agrawal, R., \& Turner, S. J. (2016). Treatment initiation patterns, modifications, and medication adherence among newly diagnosed heart failure patients: A retrospective claims database analysis. Journal of Managed Care \& Specialty Pharmacy, 22(5), 561-571. https://doi.org/10.18553/jmcp.2016.22.5.561

Ellrodt, A. G., Fonarow, G. C., Schwamm, L. H., Albert, N., Bhatt, D. L., Cannon, C. P., Hernandez, A. F., Hlatky, M. A., Luepker, R. V., Peterson, P. N., Reeves, M., \& Smith, E. E. (2013). Synthesizing lessons learned from Get With The Guidelines: The value of disease-based registries in improving quality and outcomes. Circulation, 128(22), 24472460. https://doi.org/10.1161/01.cir.0000435779.48007.5c

Florida Department of Health. (2018). County Chronic Disease Profile-2018: Duval. Florida Health. http://www.flhealthcharts.com/ChartsReports/rdPage.aspx?rdReport=ChartsProfiles.Count yChronicDiseaseProfile

Fonarow, G. C. (2011). Improving quality of care and outcomes for heart failure. Circulation Journal, 75(8), 1783-1790. https://doi.org/10.1253/circj.CJ-11-0582

Fonarow, G. C., Albert, N. M., Curtis, A. B., Gheorghiade, M., Liu, Y., Mehra, M. R., O’Connor, C. M., Reynolds, D., Walsh, M. N., \& Yancy, C. W. (2012). Incremental reduction in risk of death associated with use of guideline-recommended therapies in patients with heart failure: A nested case-control analysis of IMPROVE HF. Journal of the American Heart Association, 1(1). https://doi.org/10.1161/JAHA.111.000018

Gilstrap, L. G., Stevenson, L. W., Small, R., Parambi, R., Hamershock, R., Greenberg, J., Carr, C., Ghazinouri, R., Rathman, L., Han, E., Mehra, M. R., \& Desai, A. S. (2018). Reasons 
for guideline nonadherence at heart failure discharge. Journal of the American Heart Association, 7(15). https://doi.org/10.1161/JAHA.118.008789

Green, B. N., \& Johnson, C. D. (2015). Interprofessional collaboration in research, education, and clinical practice: Working together for a better future. The Journal of Chiropractic Education, 29(1), 1-10. https://doi.org/10.7899/JCE-14-36

Heidenreich, P. A., Zhao, X., Hernandez, A. F., Yancy, C. W., Schwamm, L. H., Albert, N. M., \& Fonarow, G. C. (2014). Impact of an expanded hospital recognition program for heart failure quality of care. Journal of the American Heart Association, 3(5). https://doi.org/10.1161/JAHA.114.000950

Iowa Model Collaborative, Buckwalter, K. C., Cullen, L., Hanrahan, K., Kleiber, C., McCarthy, A. M., Rakel, B., Steelman, V., Tripp-Reimer, T., Tucker, S., \& Authored on behalf of the Iowa Model Collaborative. (2017). Iowa Model of Evidence-Based Practice: Revisions and Validation: Iowa Model-Revised. Worldviews on Evidence-Based Nursing, 14(3), 175-182. https://doi.org/10.1111/wvn.12223

Kilgore, M., Patel, H. K., Kielhorn, A., Maya, J. F., \& Sharma, P. (2017). Economic burden of hospitalizations of Medicare beneficiaries with heart failure. Risk Management and Healthcare Policy, 10, 63-70. https://doi.org/10.2147/RMHP.S130341

Kociol, R. D., Peterson, E. D., Hammill, B. G., Flynn, K. E., Heidenreich, P. A., Piña, I. L., Lytle, B. L., Albert, N. M., Curtis, L. H., Fonarow, G. C., \& Hernandez, A. F. (2012). National survey of hospital strategies to reduce heart failure readmissions: Findings from the Get With the Guidelines-Heart Failure registry. Circulation. Heart Failure, 5(6), 680-687. https://doi.org/10.1161/CIRCHEARTFAILURE.112.967406 
Lesyuk, W., Kriza, C., \& Kolominsky-Rabas, P. (2018). Cost-of-illness studies in heart failure: A systematic review 2004-2016. BMC Cardiovascular Disorders, 18(1), 74. https://doi.org/10.1186/s12872-018-0815-3

Lewin, K. C. (1951). Field theory in social science. Harper \& Row.

Lippincott Williams \& Wilkins (2020). American Journal of Nursing: Information for authors. American Journal of Nursing. https://journals.lww.com/ajnonline/pages/informationforauthors.aspx

Merriam-Webster. (n.d.). Protocol. In Merriam-Webster.com dictionary. Retrieved April 9, 2020, from https://www.merriam-webster.com/dictionary/protocol

Reddy, Y. N. V., \& Borlaug, B. A. (2019). Readmissions in heart failure: It's more than just the medicine. Mayo Clinic Proceedings, 94(10), 1919-1921. https://doi.org/10.1016/j.mayocp.2019.08.015

Reedman, L. A., Allegra, J. R., \& Cochrane, D. G. (2008). Increases in heart failure visits after Christmas and New Year's Day. Congestive Heart Failure, 14(6), 307-309. https://doi.org/10.1111/j.1751-7133.2008.00021.x

Regalbuto, R., Maurer, M. S., Chapel, D., Mendez, J., \& Shaffer, J. A. (2014). Joint Commission requirements for discharge instructions in patients with heart failure: Is understanding important for preventing readmissions? Journal of Cardiac Failure, 20(9), 641-649. https://doi.org/10.1016/j.cardfail.2014.06.358

Rycroft-Malone, J., Burton, C. R., Bucknall, T., Graham, I. D., Hutchinson, A. M., \& Stacey, D. (2016). Collaboration and co-production of knowledge in healthcare: Opportunities and challenges. International Journal of Health Policy and Management, 5(4), 221-223. https://doi.org/10.15171/ijhpm.2016.08 
Sevinc, S., \& Samancioglu, S. (2017). Influence of caregiver on heart failure patients' disease beliefs and compliance. Nursing and Palliative Care, 2(3). https://doi.org/10.15761/NPC.1000149

Smith, S. C., Fonarow, G. C., \& Zhao, D. (2020). Measuring and improving the quality of heart failure care globally. JAMA Network Open, 3(1), e1918642. https://doi.org/10.1001/jamanetworkopen.2019.18642

Stiffler, D. (2020, May). Heartfailure organizational quality outcomes. [Personal conversation]. Stratton, S. J. (2019). Quasi-experimental design (Pre-Test and Post-Test Studies) in prehospital and disaster research. Prehospital and Disaster Medicine, 34(6), 573-574. https://doi.org/10.1017/S1049023X19005053

The Leapfrog Group. (2020). Memorial Hospital Jacksonville. Leapfrog hospital safety grade. https://www.hospitalsafetygrade.org/h/memorial-hospital-jacksonville

Titler, M. G. (2008). The evidence for evidence-based practice implementation. In R. G. Hughes (Ed.), Patient Safety and Quality: An Evidence-Based Handbookfor Nurses. Agency for Healthcare Research and Quality (US). http://www.ncbi.nlm.nih.gov/books/NBK2659/ University of Texas. (2018). A framework for evidence-based systems-level change: CFRP policy brief. University of Texas LBJ School of Public Affairs. https://childandfamilyresearch.utexas.edu/framework-evidence-based-systems-levelchange

Wang, T. Y., Dai, D., Hernandez, A. F., Bhatt, D. L., Heidenreich, P. A., Fonarow, G. C., \& Peterson, E. D. (2011). The importance of consistent, high-quality acute myocardial infarction and heart failure care. Journal of the American College of Cardiology, 58(6), 637-644. https://doi.org/10.1016/j.jacc.2011.05.012 
Wojciechowski, E., Pearsall, T., Murphy, P., \& French, E. (2016). A case review: Integrating Lewin's Theory with Lean's System Approach for Change. Online Journal of Issues in Nursing, 21(2), 4. https://doi.org/10.3912/OJIN.Vol21No02Man04

Yamaguchi, T., Kitai, T., Miyamoto, T., Kagiyama, N., Okumura, T., Kida, K., Oishi, S., Akiyama, E., Suzuki, S., Yamamoto, M., Yamaguchi, J., Iwai, T., Hijikata, S., Masuda, R., Miyazaki, R., Hara, N., Nagata, Y., Nozato, T., \& Matsue, Y. (2018). Effect of optimizing guideline-directed medical therapy before discharge on mortality and heart failure readmission in patients hospitalized with heart failure with reduced ejection fraction. The American Journal of Cardiology, 121(8), 969-974.

https://doi.org/10.1016/j.amjcard.2018.01.006

Yancy, C. W., Januzzi, J. L., Allen, L. A., Butler, J., Davis, L. L., Fonarow, G. C., Ibrahim, N. E., Jessup, M., Lindenfeld, J., Maddox, T. M., Masoudi, F. A., Motiwala, S. R., Patterson, J. H., Walsh, M. N., \& Wasserman, A. (2018). 2017 ACC expert consensus decision pathway for optimization of heart failure treatment: Answers to 10 pivotal issues about heart failure with reduced ejection fraction. Journal of the American College of Cardiology, 71(2), 201-230. https://doi.org/10.1016/j.jacc.2017.11.025

Zamorano, J. L., \& Lozano, V. C. (2015). Impact of quality improvement initiatives in patients hospitalized for heart failure. Medicographia, 37(2), 163-169. 


\section{Appendix A}

Table A1.

Data Collection Tool

HF Discharge Medication Protocol Intervention Data

\begin{tabular}{|c|c|c|c|c|c|c|c|c|c|c|c|c|}
\hline MR \# & $\begin{array}{c}\text { Date of } \\
\text { Admission }\end{array}$ & Age & Sex & $\begin{array}{c}\text { Protocol } \\
\text { Y/N? }\end{array}$ & ARB & ARNI & $\mathrm{BB}$ & $\mathrm{AA}$ & HN & Anticoag & Flu vax & Pneumonia \\
\hline & & & & & & & & & & & & \\
\hline & & & & & & & & & & & & \\
\hline & & & & & & & & & & & & \\
\hline & & & & & & & & & & & & \\
\hline & & & & & & & & & & & & \\
\hline & & & & & & & & & & & & \\
\hline & & & & & & & & & & & & \\
\hline & & & & & & & & & & & & \\
\hline & & & & & & & & & & & & \\
\hline & & & & & & & & & & & & \\
\hline & & & & & & & & & & & & \\
\hline & & & & & & & & & & & & \\
\hline & & & & & & & & & & & & \\
\hline & & & & & & & & & & & & \\
\hline & & & & & & & & & & & & \\
\hline & & & & & & & & & & & & \\
\hline & & & & & & & & & & & & \\
\hline & & & & & & & & & & & & \\
\hline & & & & & & & & & & & & \\
\hline & & & & & & & & & 7 & & & \\
\hline & & & & & & & & & & & & \\
\hline & & & & & & & & & & & & \\
\hline & & & & & & & & & & & & \\
\hline & & & & & & & & & & & & \\
\hline & & & & & & & & & & & & \\
\hline & & & & & & & & & & & & \\
\hline & & & & & & & & & & & & \\
\hline & & & & & & & & & & & & \\
\hline & & & & & & & & & & & & \\
\hline & & & & & & & & & & & & \\
\hline
\end{tabular}




\section{HF Discharge Medication Protocol Intervention Data}

\begin{tabular}{|c|c|c|c|c|c|}
\hline Exdusion Reason & Hespitalist & $\begin{array}{l}\text { RN Encouraged } \\
\text { Protocol Y/N? }\end{array}$ & $\begin{array}{c}\text { Date of } \\
\text { Discharge }\end{array}$ & $\begin{array}{c}\text { Readmission w/in } 30 \\
\text { Days Y/N }\end{array}$ & If Y- Readmisssion Date \\
\hline & & & & & \\
\hline & & & & & \\
\hline & & & & & \\
\hline & & & & & \\
\hline & & & & & \\
\hline & & & & & \\
\hline & & & & & \\
\hline & & & & & \\
\hline & & & & & \\
\hline & & & & & \\
\hline & & & & & \\
\hline & & & & & \\
\hline & & & & & \\
\hline & & & & & \\
\hline & & & & & \\
\hline & & & & & \\
\hline & & & & & \\
\hline & & & & & \\
\hline & & & & & \\
\hline & & & & & \\
\hline & & & & & \\
\hline & & & & & \\
\hline & & & & & \\
\hline & & & & & \\
\hline & & & & & \\
\hline & & & & & \\
\hline & & & & & \\
\hline & & & & & \\
\hline & & & & & \\
\hline & & & & & \\
\hline
\end{tabular}


Table A2.

Intellectus Spreadsheet

\begin{tabular}{|c|c|c|c|c|c|c|c|c|c|c|c|}
\hline Phase & MR & Adm Date & Age & Sex & 30D_Readm & Protocol & P. Encouraged & $\mathrm{D} / \mathrm{C}$ & Week_of_Proj & Trim. & $2 \pi k$ interval \\
\hline & & & & & & & & & & & \\
\hline & & & & & & & & & & & \\
\hline & & & & & & & & & & & \\
\hline & & & & & & & & & & & \\
\hline & & & & & & & & & & & \\
\hline & & & & & & & & & & & \\
\hline & & & & & & & & & & & \\
\hline & & & & & & & & & & & \\
\hline & & & & & & & & & & & \\
\hline & & & & & & & & & & & \\
\hline & & & & & & & & & & & \\
\hline & & & & & & & & & & & \\
\hline & & & & & & & & & & & \\
\hline & & & & & & & & & & & \\
\hline & & & & & & & & & & & \\
\hline & & & & & & & & & & & \\
\hline & & & & & & & & & & & \\
\hline & & & & & & & & & & & \\
\hline & & & & & & & & & & & \\
\hline & & & & & & & & & & & \\
\hline & & & & & & & & & & & \\
\hline & & & & & & & & & & & \\
\hline & & & & & & & & & & & \\
\hline & & & & & & & & & & & \\
\hline & & & & & & & & & & & \\
\hline
\end{tabular}


Table A3.

Budget

\begin{tabular}{|c|c|c|c|}
\hline EXPENSES & & REVENUE & \\
\hline Direct & & Institutional budget support & $\$ 3670$ \\
\hline $\begin{array}{l}\text { Salary and benefits of staff for } \\
\text { meetings. } \\
\text { Approx. } 6 \text { hrs of meetings } \\
\text { - Key stakeholders (see Table 1.) } \\
\text { 4hrs/avg hourly pay } \$ 60 \\
\text { - } 5 \text { CVU charge nurses } 2 \mathrm{hrs} / \mathrm{avg} \\
\text { hourly pay } \$ 37 \\
\text { - Data analyst } 12 \mathrm{hrs} / \text { avg hourly } \\
\text { pay } \$ 35\end{array}$ & $\begin{array}{l}\$ 2880 \\
\$ 370 \\
\$ 420\end{array}$ & & \\
\hline Total Expenses & $\$ 3670$ & Total Revenue & $\$ 3670$ \\
\hline Net Balance & $\$ 0$ & & \\
\hline
\end{tabular}




\section{Figure A1.}

The Iowa Model Revised

\section{The lowa Model Revised: Evidence-Based Practice to Promote Excellence in Health Care}

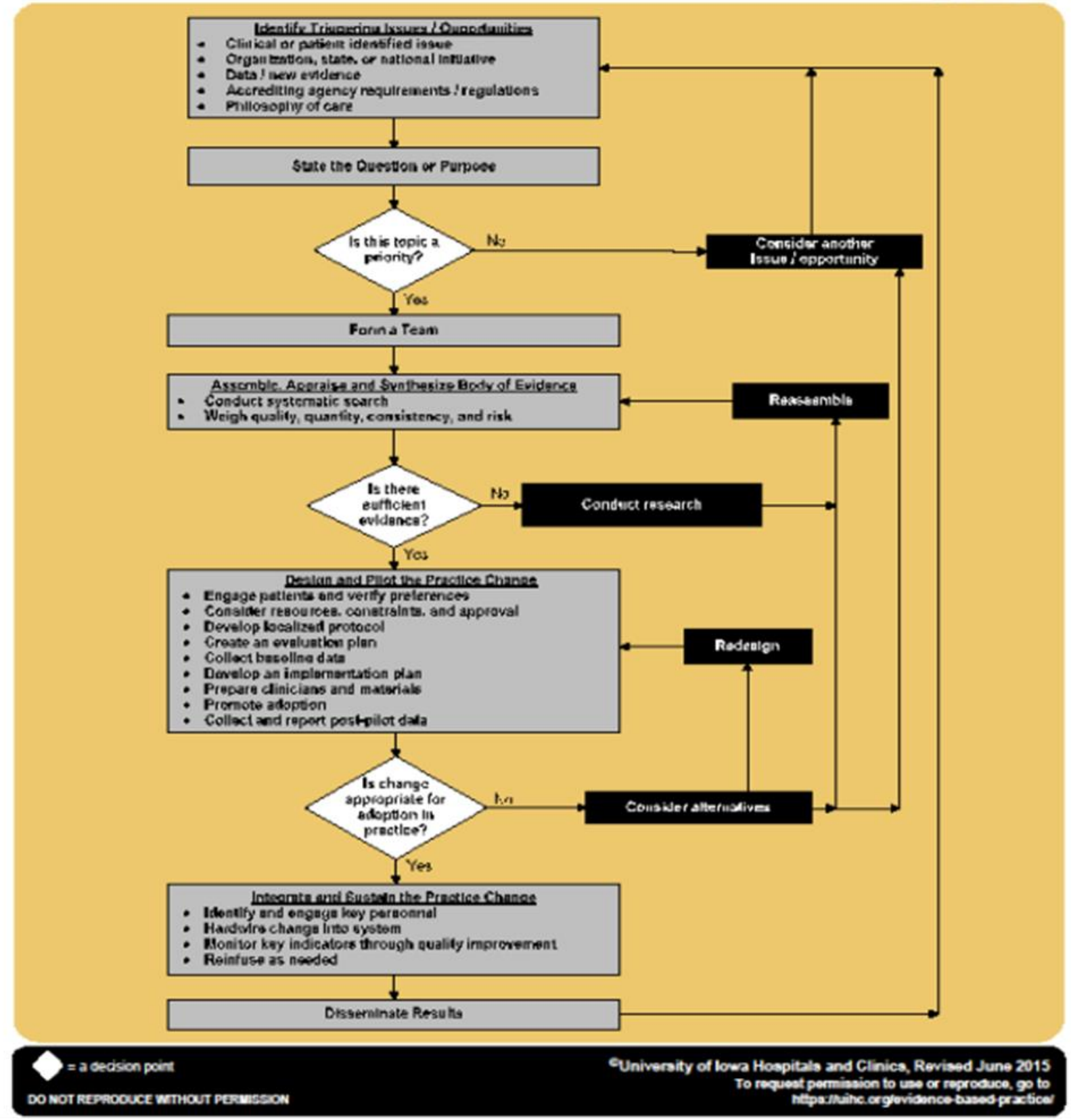

Note. Iowa flow chart diagram from "Iowa Model of Evidence-Based Practice." Iowa Model Collaborative. (2017). Iowa model of evidence-based practice: Revisions and validation. Worldviews on Evidence-Based Nursing, 14(3), 175-182. Doi:10.1111/wvn.12223. Copyright 2015 by University of Iowa Hospitals and Clinics. 


\section{Figure A2.}

\section{PRISMA Diagram}

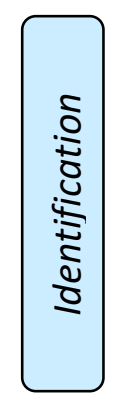

Records identified through advanced search of University of St. Augustine for Health Sciences database searching heart failure, guidelines, readmission

$$
(n=24)
$$

Additional records identified through other sources such as reference searches

$$
(\mathrm{n}=4)
$$

Records after duplicates removed

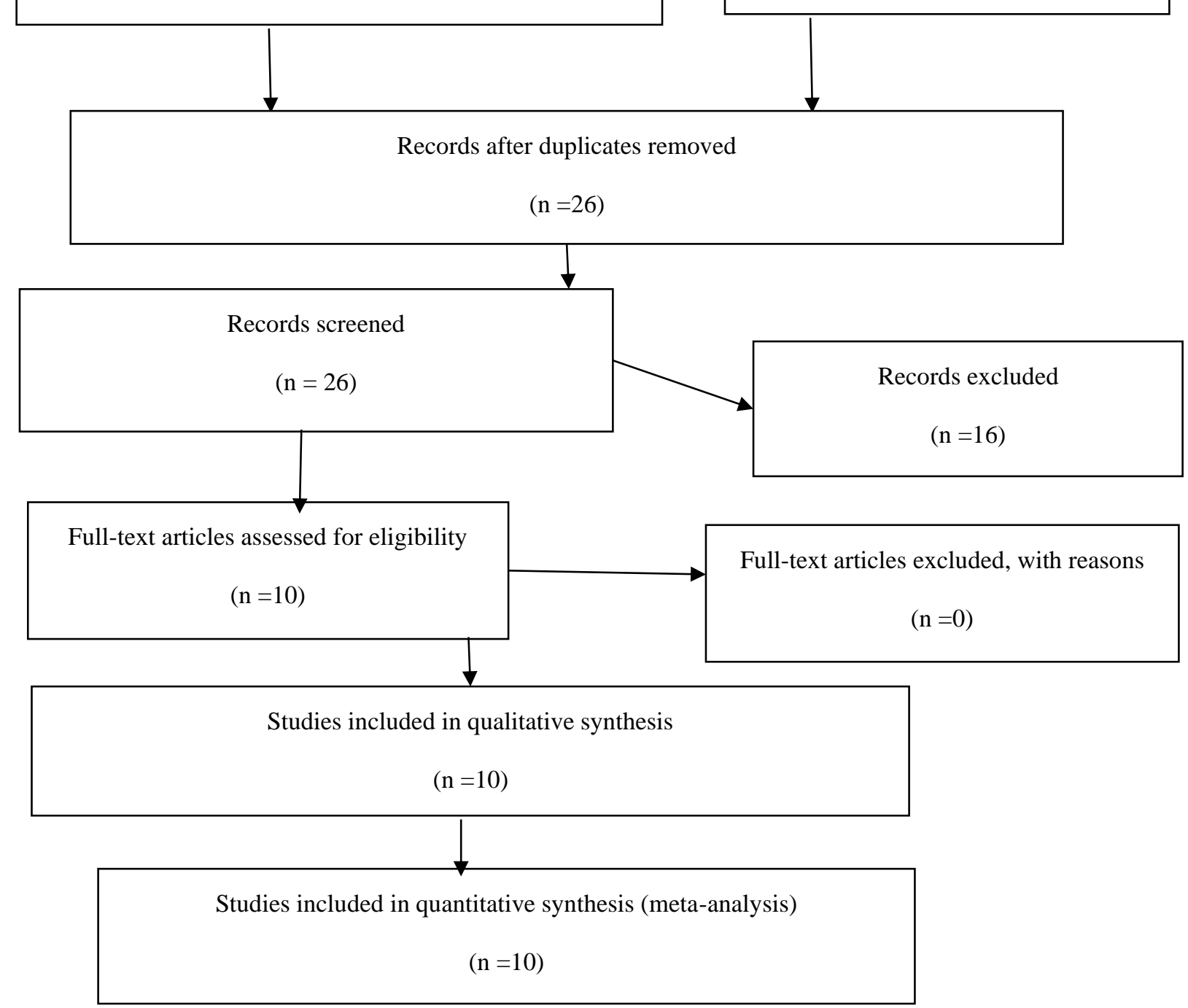

Note. Prisma flow chart diagram from "Preferred Reporting Items for Systematic Reviews and Meta-analyses: The PRISMA Statement," by D. Moher, A. Liberati, J. Tetzlaff, \& D. G. Altman, 2009, Annals of Internal Medicine, 151(4), p. 267 (http://dx.doi.org/10.7326/0003-4819-151-4-200908180-00135). Copyright 2009 by The American College of Physicians. 
Figure A3.

\section{Get With The Guidelines: Target HF Discharge Checklist}

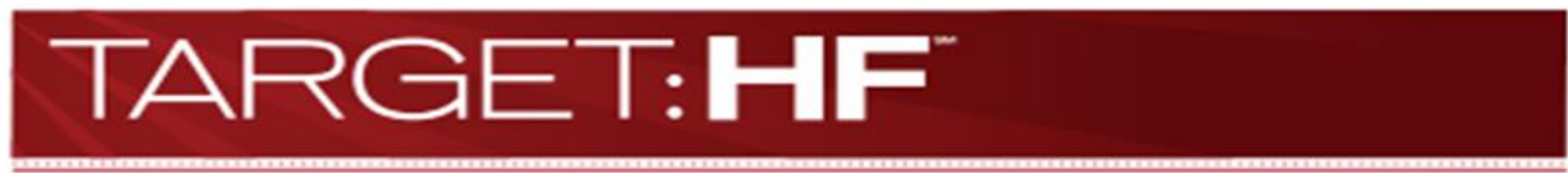

\section{HEART FAILURE DISCHARGE CHECKLIST}

Please complete all boxes for each HF indicator:

Admit Date:

Adrmit Unit:

Discharge Date:

Discharge Unit:

Attending Physician: HF Etiology:

Follow-up appointment (date/time/location):

\begin{tabular}{|c|c|c|c|}
\hline Complete All Boxes for Each HF Indicator & YES & NO & $\begin{array}{l}\text { Reason Not } \\
\text { Done/Contraindications }\end{array}$ \\
\hline Angiotensin-converting enzyme inhibitor (ff LVSD) & & & $\square \mathrm{NA} \quad \square \mathrm{Cl}$ \\
\hline $\begin{array}{l}\text { Angioterain receptor blocker } \\
\text { (if LVSD and ACEI not tolerated) }\end{array}$ & & & $\square \mathrm{NA} \quad \square \mathrm{Cl}$ \\
\hline $\begin{array}{l}\text { Angioterain receptor/neprilyein inhibitor (f LVSD, and } \\
\text { in place of an ACEl or ARB) }\end{array}$ & & & $\square \mathrm{NA} \quad \square \mathrm{Cl}$ \\
\hline $\begin{array}{l}\text { B-Blocker (if LVSD, use only carvedilal, } \\
\text { metoprolol succinate, or besoprolol) }\end{array}$ & & & $\square \mathrm{NA} \quad \square \mathrm{Cl}$ \\
\hline 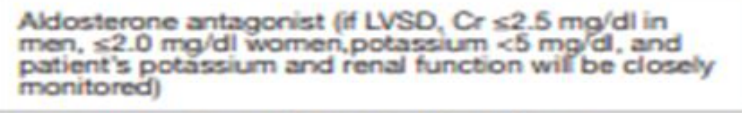 & & & $\square \mathrm{NA} \quad \square \mathrm{Cl}$ \\
\hline $\begin{array}{l}\text { Hydralazine/nitrate (if self-identified African } \\
\text { American and LVSO) }\end{array}$ & & & $\square \mathrm{NA} \quad \square \mathrm{Cl}$ \\
\hline \multicolumn{4}{|l|}{ 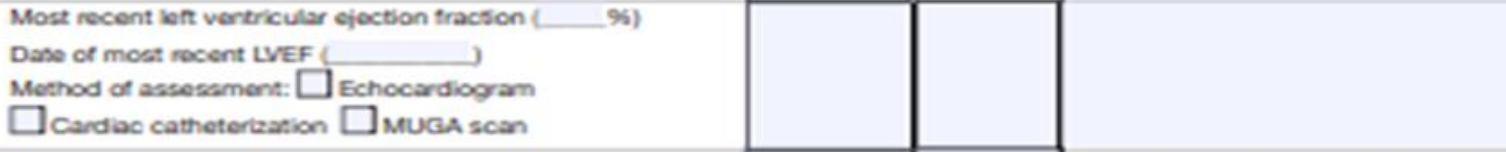 } \\
\hline $\begin{array}{l}\text { Anticoagulation for atrial fibrillation or flutter } \\
\text { (permanent of paroxysmal) or other indications }\end{array}$ & & & $\square \mathrm{NA} \quad \square \mathrm{Cl}$ \\
\hline $\begin{array}{l}\text { Precipitating factors for HF decompensation } \\
\text { identified and addressed }\end{array}$ & & & $\square \mathrm{NA} \quad \square \mathrm{Cl}$ \\
\hline Blood pressure controlled (<140/90 mm Hg) & & & $\square \mathrm{NA} \quad \square \mathrm{Cl}$ \\
\hline Pneumococcal vaccination administered & & & $\square^{\mathrm{NA}} \square \mathrm{Cl}$ \\
\hline Influenza vaccination administered javing fu season & & & $\square^{\mathrm{NA}} \quad \square_{\mathrm{Cl}}$ \\
\hline $\begin{array}{l}\text { EP consult if sudden death risk or potential } \\
\text { candidate for decide therapy }\end{array}$ & & & $\square \mathrm{NA} \quad \square \mathrm{Cl}$ \\
\hline \multicolumn{2}{|l|}{ Cans } & \multicolumn{2}{|r|}{ Patient Sticker Here } \\
\hline
\end{tabular}

American Heart Association. (n.d.). Target heart failure: Heart failure discharge checklist. American Heart Association. https://www.heart.org/-/media/files/professional/quality-improvement/target-heart-failure/targethf-dischargechecklist-ucm_496869.pdf?la=en 


\section{Appendix B}

Figure 1

John Hopkin's Evidence Level and Quality Guide

\begin{tabular}{|c|c|}
\hline Evidence Levels & Quality Ratings \\
\hline Level I & \multirow{4}{*}{$\begin{array}{l}\text { QuaNtitative Studies } \\
\text { A High quality: Consistent, generalizable results; sufficient sample size for the study design; adequate } \\
\text { control; definitive conclusions; consistent recommendations based on comprehensive literature review that } \\
\text { includes thorough reference to scientific evidence. } \\
\text { B Good quality: Reasonably consistent results; sufficient sample size for the study design; some control, } \\
\text { fairly definitive conclusions; reasonably consistent recommendations based on fairly comprehensive } \\
\text { literature review that includes some reference to scientific evidence. } \\
\text { C Low quality or maior flaws: Little evidence with inconsistent results; insufficient sample size for the } \\
\text { study design; conclusions cannot be drawn. } \\
\text { OuaLitative Studies }\end{array}$} \\
\hline $\begin{array}{l}\text { Experimental study, randomized controlled trial } \\
\text { (RCT) }\end{array}$ & \\
\hline $\begin{array}{l}\text { Explanatory mixed method design that indudes } \\
\text { only a level I quaNtitative study } \\
\text { Systematic review of RCTs, with or without meta }\end{array}$ & \\
\hline & \\
\hline $\begin{array}{l}\text { Level II } \\
\text { Quasi-experimental study } \\
\text { Explanatory mixed method design that indudes } \\
\text { only a level II quaNtitative study }\end{array}$ & $\begin{array}{l}\text { No commonly agreed-on principles exist for judging the quality of qualitative studies. It is a subjective } \\
\text { process based on the extent to which study data contributes to synthesis and how much information is known } \\
\text { about the researchers' efforts to meet the appraisal criteria. }\end{array}$ \\
\hline $\begin{array}{l}\text { Systematic review of a combination of RCTs and } \\
\text { quasi-experimental studies, or quasi- }\end{array}$ & \multirow{4}{*}{$\begin{array}{l}\text { For meta-synthesis, there is preliminary agreement that quality assessments of individual studies should be } \\
\text { made before synthesis to screen out poor-quality studies. } \\
\text { A/B High/Good quality is used for single studies and meta-syntheses }{ }^{2} \text {. } \\
\text { The report discusses efforts to enhance or evaluate the quality of the data and the overall inquiry in } \\
\text { sufficient detail; and it describes the specific techniques used to enhance the quality of the inquiry. } \\
\text { Evidence of some or all of the following is found in the report: }\end{array}$} \\
\hline experimental studies only, with or without meta- & \\
\hline & \\
\hline \multirow{8}{*}{$\begin{array}{l}\text { Level III } \\
\text { Nonexperimental study } \\
\text { Systematic review of a combination of RCTs, } \\
\text { quasi-experimental and nonexperimental studies, } \\
\text { or nonexperimental studies only, with or without } \\
\text { meta-analysis } \\
\text { Exploratory, convergent, or multiphasic mixed } \\
\text { methods studies } \\
\text { Explanatory mixed method design that indudes_- } \\
\text { only a level III quaNtitative study } \\
\text { QuaLitative study Meta-synthesis }\end{array}$} & \\
\hline & - Transparency: Describes how information was documented to justify decisions, how data were \\
\hline & $\begin{array}{l}\text { - Diligence: Reads and rereads data to check interpretations; seeks opportunity to find multiple } \\
\text { sources to corroborate evidence. }\end{array}$ \\
\hline & Verification: The process of checking, confirming, and ensuring methodologic coherence. \\
\hline & $\begin{array}{l}\text { - Self-reflection and scrutiny: Being continuously aware of how a researcher's experiences, } \\
\text { background, or prejudices might shape and bias analysis and interpretations. }\end{array}$ \\
\hline & $\begin{array}{l}\text { - Participant-driven inquiry: Participants shape the scope and breadth of questions; analysis and } \\
\text { interpretation give voice to those who participated. }\end{array}$ \\
\hline & - Insightful interpretation: Data and knowledge are linked in meaningful ways to relevant literature. \\
\hline & $\begin{array}{l}\text { C Low quality studies contribute little to the overall review of findings and have few, if any, of the features } \\
\text { listed for high/good quality. }\end{array}$ \\
\hline
\end{tabular}




\begin{tabular}{|c|c|}
\hline Evidence Levels & Quality Ratings \\
\hline $\begin{array}{l}\text { Level IV } \\
\text { Opinion of respected authorities and/or } \\
\text { nationally recognized expert committees or } \\
\text { consensus panels based on scientific evidence } \\
\text { Includes: } \\
\text { - Clinical practice guidelines } \\
\text { - Consensus panels/position statements }\end{array}$ & $\begin{array}{l}\text { A High quality: Material officially sponsored by a professional, public, or private organization or a government } \\
\text { agency; documentation of a systematic literature search strategy; consistent results with sufficient numbers of } \\
\text { well-designed studies; criteria-based evaluation of overall scientific strength and quality of induded studies and } \\
\text { definitive conclusions; national expertise clearly evident; developed or revised within the past five years } \\
\text { B Good quality; Material officially sponsored by a professional, public, or private organization or a government } \\
\text { agency; reasonably thorough and appropriate systematic literature search strategy; reasonably consistent } \\
\text { results, sufficient numbers of well-designed studies; evaluation of strengths and limitations of included studies } \\
\text { with fairly definitive conclusions; national expertise clearly evident; developed or revised within the past five } \\
\text { years } \\
\text { C Low quality or maior flaws: Material not sponsored by an official organization or agency; undefined, poorly } \\
\text { defined, or limited literature search strategy; no evaluation of strengths and limitations of included studies, } \\
\text { insufficient evidence with inconsistent results, conclusions cannot be drawn; not revised within the past five } \\
\text { years }\end{array}$ \\
\hline $\begin{array}{l}\text { Level } \mathbf{V} \\
\text { Based on experiential and nonresearch evidence } \\
\text { Includes: } \\
\text { - Integrative reviews } \\
\text { - Literature reviews } \\
\text { - Quality improvement, program, or financial } \\
\text { evaluation } \\
\text { - Case reports } \\
\text { - Opinion of nationally recognized expert(s) } \\
\text { based on experiential evidence }\end{array}$ & $\begin{array}{l}\text { Organizational Experience (quality improvement, program or financial evaluation) } \\
\text { A High quality: Clear aims and objectives; consistent results across multiple settings; formal quality } \\
\text { improvement, financial, or program evaluation methods used; definitive conclusions; consistent } \\
\text { recommendations with thorough reference to scientific evidence } \\
\text { B Good quality: Clear aims and objectives; consistent results in a single setting; formal quality improvement, } \\
\text { financial, or program evaluation methods used; reasonably consistent recommendations with some reference to } \\
\text { scientific evidence } \\
\text { C Low quality or maior flaws: Unclear or missing aims and objectives; inconsistent results; poorly defined } \\
\text { quality improvement, financial, or program evaluation methods; recommendations cannot be made } \\
\text { Integrative Review, Literature Review, Expert Opinion, Case Report, Community Standard, } \\
\text { Clinician Experience, Consumer Preference } \\
\text { A Hiah quality: Expertise is clearly evident; draws definitive conclusions; provides scientific rationale; thought } \\
\text { leader(s) in the field } \\
\text { B Good auality: Expertise appears to be credible; draws fairly definitive conclusions; provides logical argument } \\
\text { for opinions } \\
\text { C Low quality or major flaws: Expertise is not discernable or is dubious; conclusions cannot be drawn }\end{array}$ \\
\hline
\end{tabular}

2 Adopted from Polit \& Beck (2017).

(๔) 2017 The Johns Hopkins Hospital/ Johns Hopkins University School of Nursing

Institute for Johns Hopkins Nursing. (n.d.). JHNEBP model and tools-permission. Johns Hopkins Nursing.

https://www.ijhneducation.org/node/18409/done?sid=71039\&token=3dd2085cfcf2ba222ffa8d34b0e21506 


\section{Appendix C}

\section{Table 1}

Summary of Primary Research Evidence

\begin{tabular}{|c|c|c|c|c|c|c|c|}
\hline Citation & $\begin{array}{l}\text { Quality } \\
\text { Grade }\end{array}$ & Question & $\begin{array}{l}\text { Search } \\
\text { Strategy }\end{array}$ & $\begin{array}{l}\text { Inclusion/ } \\
\text { Exclusion Criteria }\end{array}$ & $\begin{array}{l}\text { Data Extraction and } \\
\text { Analysis }\end{array}$ & Key Findings & $\begin{array}{l}\text { Usefulness/Recommendation/ } \\
\text { Implications }\end{array}$ \\
\hline $\begin{array}{l}\text { Kociol et al., } \\
2012 .\end{array}$ & $\begin{array}{l}\text { Level II } \\
\text { Grade B }\end{array}$ & $\begin{array}{l}\text { Surveying } \\
\text { patients whose } \\
\text { hospital } \\
\text { participates in the } \\
\text { Get With the } \\
\text { Guidelines-Heart } \\
\text { Failure quality } \\
\text { improvement } \\
\text { program, What } \\
\text { are the common } \\
\text { processes of care } \\
\text { aimed at } \\
\text { reducing } \\
\text { readmissions? }\end{array}$ & None & $\begin{array}{l}100 \text { randomly selected } \\
\text { hospitals participating } \\
\text { in GWTG. Patients } \\
\text { were eligible for } \\
\text { inclusion in the registry } \\
\text { if they were admitted } \\
\text { to a hospital for an } \\
\text { episode of worsening } \\
\text { heart failure or } \\
\text { developed significant } \\
\text { heart failure symptoms } \\
\text { during a hospitalization } \\
\text { for which heart failure } \\
\text { was the primary } \\
\text { discharge diagnosis. }\end{array}$ & $\begin{array}{l}\text { Used a telephone survey } \\
\text { developed for this study } \\
\text { and administered the } \\
\text { survey to personnel at } \\
\text { randomly selected } \\
\text { hospitals participating in } \\
\text { the GWTG-HF quality } \\
\text { improvement initiative. } \\
\text { We present hospital } \\
\text { characteristics by } \\
\text { readmission quartile, } \\
\text { using means with SDs for } \\
\text { continuous variables and } \\
\text { frequencies with } \\
\text { percentages for } \\
\text { categorical variables. } \\
\text { Assessed associations } \\
\text { between quartiles and all } \\
\text { variables using Cochran- } \\
\text { Mantel-Haenszel nonzero } \\
\text { correlation tests. Scored } \\
\text { in each domain overall } \\
\text { and by readmission } \\
\text { quartile. Assessed } \\
\text { associations between } \\
\text { domain scores and } \\
\text { readmission quartiles } \\
\text { using Cochran-Mantel- } \\
\text { Haenszel nonzero } \\
\text { correlation tests. Tested } \\
\text { for associations between } \\
\text { domain scores and } \\
\text { continuous risk- } \\
\text { standardized readmission } \\
\text { rate. }\end{array}$ & $\begin{array}{l}\text { Modest association } \\
\text { between more } \\
\text { complete discharge } \\
\text { and transitional care } \\
\text { processes and lower } \\
\text { 30-day readmission } \\
\text { rates (Kociol et al., } \\
2012 \text { ) }\end{array}$ & $\begin{array}{l}\text { The use of computerized reminders } \\
\text { and discharge checklists was used in } \\
<50 \% \text { of the sites surveyed. } \\
\text { Computerized discharge instructions } \\
\text { or pop-up reminders to prescribe } \\
\text { evidence-based therapies were only } \\
\text { used by } 24 \% \text { and } 18 \% \text { of hospitals, } \\
\text { respectively (Kociol et al., 2012). This } \\
\text { shows a lack in use of tools provided } \\
\text { by GWTG, and need for further } \\
\text { studies based on the effectiveness of } \\
\text { checklists and guideline-based } \\
\text { prescribing. }\end{array}$ \\
\hline
\end{tabular}




\begin{tabular}{|c|c|c|c|c|c|c|c|}
\hline $\begin{array}{l}\text { Gilstrap et } \\
\text { al., } 2018 .\end{array}$ & $\begin{array}{l}\text { Level II } \\
\text { Grade B }\end{array}$ & $\begin{array}{l}\text { What is the } \\
\text { frequency and } \\
\text { reasons for } \\
\text { noncompliance } \\
\text { with heart failure } \\
\text { (HF) guidelines } \\
\text { at the time of } \\
\text { hospital } \\
\text { discharge from } \\
\text { both academic } \\
\text { and community } \\
\text { hospitals? }\end{array}$ & None & $\begin{array}{l}\text { All patients admitted to } \\
\text { the HF services of } \\
\text { either hospital during } \\
\text { the study period with a } \\
\text { primary diagnosis of } \\
\text { HF were considered for } \\
\text { inclusion. Exclusion } \\
\text { criteria included new- } \\
\text { onset HF, end-stage } \\
\text { renal disease requiring } \\
\text { hemodialysis, or end- } \\
\text { stage HF requiring } \\
\text { palliative care. Patients } \\
\text { admitted for } \\
\text { consideration of } \\
\text { advanced therapies, } \\
\text { including mechanical } \\
\text { circulatory support or } \\
\text { transplantation, were } \\
\text { also excluded. }\end{array}$ & $\begin{array}{l}\text { Data collection methods } \\
\text { not shared. Descriptive } \\
\text { statistics are reported with } \\
\text { frequencies, percentages, } \\
\text { means (for normally } \\
\text { distributed data), and } \\
\text { medians (for non-normal } \\
\text { data) with between- } \\
\text { sample comparisons } \\
\text { conducted using standard } \\
\text { parametric or } \\
\text { nonparametric tests, as } \\
\text { appropriate. Fisher exact } \\
\text { and } \chi 2 \text { tests were used to } \\
\text { compare changes in } \\
\text { congestion status, } \\
\text { perfusion status, } \\
\text { neurohormonal dosing, } \\
\text { and readmission rates } \\
\text { between groups. } \\
\text { Statistical analyses were } \\
\text { conducted using SAS v9.3 } \\
\text { (SAS Institute). }\end{array}$ & $\begin{array}{l}\text { Among all HF } \\
\text { discharges, } 25 \% \\
\text { were done with } \\
\text { residual congestion } \\
\text { Among discharges } \\
\text { of patients with HR } \\
\text { with reduced } \\
\text { ejection fraction, } \\
37 \% \text { were } \\
\text { discharged on less } \beta \text { - } \\
\text { blocker and } 46 \% \\
\text { were discharged on } \\
\text { less angiotensin- } \\
\text { converting enzyme } \\
\text { inhibitor or } \\
\text { angiotensin II } \\
\text { receptor blocker } \\
\text { compared with } \\
\text { admission. } \\
\text { Renal dysfunction } \\
\text { was the most } \\
\text { common reason for } \\
\text { discharge with } \\
\text { residual congestion, } \\
\text { and hypotension was } \\
\text { the most common } \\
\text { reason for discharge } \\
\text { with no or decreased } \\
\text { neurohormonal } \\
\text { therapy. Recent } \\
\text { inotropic use was } \\
\text { also commonly cited } \\
\text { at the academic } \\
\text { hospital. }\end{array}$ & $\begin{array}{l}\text { Clinicians frequently deviate from } \\
\text { guidelines at both academic and } \\
\text { community hospitals. However, this } \\
\text { may not always indicate poor-quality } \\
\text { care. Application of traditional HF } \\
\text { guidelines, which were developed in } \\
\text { stable HF populations, at the time of } \\
\text { hospital discharge is increasingly } \\
\text { limited by hypotension, renal } \\
\text { dysfunction, and recent inotrope use in } \\
\text { more tenuous HF patients. Patients } \\
\text { with renal dysfunction, hypotension, } \\
\text { and recent inotrope use merit further } \\
\text { study to determine best practices and } \\
\text { possibly to adjust quality metrics for } \\
\text { HF severity. }\end{array}$ \\
\hline $\begin{array}{l}\text { Bergethon et } \\
\text { al., } 2016 .\end{array}$ & $\begin{array}{l}\text { Level III } \\
\text { Grade B }\end{array}$ & $\begin{array}{l}\text { What are the } \\
\text { trends in } 30 \text {-day, } \\
\text { all-cause } \\
\text { readmission rates } \\
\text { from } 2009 \text { to } \\
2012 \text { among } \\
\text { patients with } \\
\text { heart failure and } \\
\text { what are the care } \\
\text { processes and } \\
\text { hospital factors } \\
\text { associated with } \\
\text { the trends? }\end{array}$ & None & $\begin{array}{l}\text { Patients were included } \\
\text { if they were discharged } \\
\text { on or before November } \\
1 \text { of each calendar } \\
\text { year. Patients were } \\
\text { excluded from the } \\
\text { analysis if they were } \\
\text { ineligible for fee-for- } \\
\text { service Medicare at the } \\
\text { time of discharge from } \\
\text { the index } \\
\text { hospitalization, they } \\
\text { died in hospital, their } \\
\text { discharge status was } \\
\text { missing or not }\end{array}$ & $\begin{array}{l}\text { Combined data from the } \\
\text { GWTG-HF registry, the } \\
\text { American Hospital } \\
\text { Association Survey on } \\
\text { Hospital Characteristics, } \\
\text { the Dartmouth Atlas of } \\
\text { Healthcare, CMS } \\
\text { administrative claims, and } \\
\text { the CMS Hospital } \\
\text { Compare data. } \\
\text { Presented categorical } \\
\text { variables as frequencies } \\
\text { and percentages and } \\
\text { continuous variables as } \\
\text { means with SDs, medians, }\end{array}$ & $\begin{array}{l}\text { Several hospital } \\
\text { factors were } \\
\text { associated with } \\
\text { relative rates of } \\
\text { readmission, with } \\
\text { structural factors, } \\
\text { particularly teaching } \\
\text { hospital status, } \\
\text { likely contributing } \\
\text { the most to } \\
\text { readmission rates as } \\
\text { opposed to } \\
\text { modifiable care } \\
\text { delivery factors. }\end{array}$ & $\begin{array}{l}\text { There has been slight improvement in } \\
\text { 30-day all-cause readmission rates in } \\
\text { patients with heart failure, few } \\
\text { hospitals have seen large success. } \\
\text { More research is needed to understand } \\
\text { how to improve hospital readmission } \\
\text { for patients with heart failure } \\
\text { regarding how to identify and } \\
\text { implement best practices nationally. }\end{array}$ \\
\hline
\end{tabular}




\begin{tabular}{|c|c|c|c|c|c|c|c|}
\hline & & & & $\begin{array}{l}\text { documented, they left } \\
\text { against medical advice, } \\
\text { or they were } \\
\text { transferred to an acute } \\
\text { care facility. Hospitals } \\
\text { were excluded if they } \\
\text { had fewer than } 10 \\
\text { patients in GWTG-HF } \\
\text { program in } 2009 \text { or } \\
2012 .\end{array}$ & $\begin{array}{l}\text { and interquartile ranges. } \\
\text { Compared categorical } \\
\text { variables using Fisher } \\
\text { exact test. Compared } \\
\text { continuous variables } \\
\text { using Kruskal-Wallis } \\
\text { tests. Evaluated the } \\
\text { relationship between } \\
\text { baseline readmission rates } \\
\text { and relative rate reduction } \\
\text { by calculating relative } \\
\text { change in 30-day risk- } \\
\text { adjusted readmission rates } \\
\text { between 2009 and } 2012 \text { as } \\
\text { a function of quartiles of } \\
\text { 2009 risk-adjusted } \\
\text { readmission rates using a } \\
\text { Kruskal-Wallis test. } \\
\text { Determined trends across } \\
\text { admission years using an } \\
\text { unadjusted linear } \\
\text { regression model with } \\
\text { generalized estimating } \\
\text { equation to account for in- } \\
\text { hospital clustering, with } \\
\text { percent readmission as the } \\
\text { outcome and admission } \\
\text { year as the explanatory } \\
\text { variable. Performed a } \\
\text { sensitivity analysis } \\
\text { designed to ensure that } \\
\text { our study population had } \\
\text { similar rates of relative } \\
\text { change in readmissions to } \\
\text { hospitals nationwide. }\end{array}$ & & \\
\hline $\begin{array}{l}\text { Wang et al., } \\
2011 .\end{array}$ & $\begin{array}{l}\text { Level II } \\
\text { Grade B }\end{array}$ & $\begin{array}{l}\text { To what degree is } \\
\text { hospital } \\
\text { performance for } \\
\text { acute myocardial } \\
\text { infarction (AMI) } \\
\text { and heart failure } \\
\text { (HF) care } \\
\text { processes } \\
\text { correlated? }\end{array}$ & None & $\begin{array}{l}\text { Compared hospital } \\
\text { performance of the } \\
\text { Centers for Medicare } \\
\text { \& Medicaid Services } \\
\text { AMI and HF core } \\
\text { measures in } 283 \\
\text { hospitals submitting } 10 \\
\text { or more patients to the } \\
\text { Get With The } \\
\text { Guidelines AMI and } \\
\text { HF programs between } \\
\text { January } 2005 \text { and April } \\
2009 \text {. }\end{array}$ & $\begin{array}{l}\text { Data were collected via a } \\
\text { web-based patient } \\
\text { management tool that } \\
\text { provides decision support } \\
\text { with real-time online } \\
\text { reporting features. } \\
\text { Descriptive statistics were } \\
\text { used to characterize } \\
\text { hospital-level } \\
\text { performance of AMI and } \\
\text { HF core measures. The } \\
\text { correlation between } \\
\text { hospital performance in } \\
\text { AMI measures and }\end{array}$ & $\begin{array}{l}\text { Found only a modest } \\
\text { correlation between } \\
\text { a hospital's } \\
\text { performance in AMI } \\
\text { measures compared } \\
\text { with its performance } \\
\text { in HF measures. } \\
\text { However, centers } \\
\text { that excel at both } \\
\text { AMI and HF } \\
\text { measures have better } \\
\text { performance than } \\
\text { centers that excel at } \\
\text { neither or at each }\end{array}$ & $\begin{array}{l}\text { Refining of quality improvement } \\
\text { strategies is needed to optimize the } \\
\text { consistency of hospital quality of } \\
\text { cardiovascular care. Assessments of } \\
\text { hospital performance may be aligned } \\
\text { better with the overall quality of } \\
\text { inpatient cardiovascular care, rather } \\
\text { than the delivery of care within a } \\
\text { specific therapeutic area. }\end{array}$ \\
\hline
\end{tabular}




\begin{tabular}{|c|c|c|c|c|c|c|c|}
\hline & & & & & $\begin{array}{l}\text { hospital performance in } \\
\text { HF measures was } \\
\text { determined using } \\
\text { Spearman correlation } \\
\text { coefficients. }\end{array}$ & $\begin{array}{l}\text { alone, and these } \\
\text { centers have } \\
\text { significantly better } \\
\text { patient outcomes. }\end{array}$ & \\
\hline $\begin{array}{l}\text { Heidenreich } \\
\text { et al., } 2014 .\end{array}$ & $\begin{array}{l}\text { Level III } \\
\text { Grade B }\end{array}$ & $\begin{array}{l}\text { What is the } \\
\text { impact of the } \\
\text { Plus Awards on } \\
\text { overall quality of } \\
\text { heart failure care } \\
\text { for hospitals } \\
\text { participating in } \\
\text { the GWTG-HF } \\
\text { program? }\end{array}$ & None & $\begin{array}{l}\text { Identified all patients } \\
\text { hospitalized with heart } \\
\text { failure from } 2008 \\
\text { through September } \\
\text { 2011. Excluded } \\
\text { patients without } \\
\text { laboratory data } \\
\text { reported and those } \\
\text { from hospitals that did } \\
\text { not report medical } \\
\text { history data routinely, } \\
\text { patients who died } \\
\text { during hospitalization, } \\
\text { and those who were } \\
\text { transferred to another } \\
\text { healthcare or acute care } \\
\text { facility or who left } \\
\text { against medical advice. }\end{array}$ & $\begin{array}{l}\text { Patient and hospital } \\
\text { characteristics, } \\
\text { achievement, and quality } \\
\text { measures were } \\
\text { summarized descriptively } \\
\text { for the preprogram and } \\
\text { program periods. P values } \\
\text { were based on Pearson } \\
\text { chi-square tests or } \\
\text { Wilcoxon tests. Logistic } \\
\text { regression was used to } \\
\text { assess the relationship } \\
\text { between increasing } \\
\text { calendar time in months } \\
\text { and odds of outcome. A } \\
\text { secondary analysis } \\
\text { examined differences in } \\
\text { use of the 9-quality } \\
\text { metrics between Plus } \\
\text { Awards and non-Plus } \\
\text { Awards hospitals. } \\
\text { Analyses were performed } \\
\text { using SAS software } \\
\text { (version 9.2; SAS } \\
\text { Institute). }\end{array}$ & $\begin{array}{l}\text { The study did not } \\
\text { show that use of } \\
\text { recommended } \\
\text { treatments uniformly } \\
\text { accelerated } \\
\text { following onset of } \\
\text { the program. There } \\
\text { was continued } \\
\text { improvement in the } \\
\text { achievement } \\
\text { measures with no } \\
\text { erosion in } \\
\text { performance on any } \\
\text { of these key metrics. } \\
\text { Observed uptake of } \\
\text { some targeted } \\
\text { therapies } \\
\text { accelerating after } \\
\text { recognition (ICD } \\
\text { use) and others } \\
\text { decelerating } \\
\text { (vaccinations). }\end{array}$ & $\begin{array}{l}\text { Increases in all quality measures were } \\
\text { observed over time; however, the use } \\
\text { of several treatments remained low, } \\
\text { including use of hydralazine-nitrate } \\
\text { combination for patients of African } \\
\text { descent and aldosterone antagonists in } \\
\text { appropriate candidates. Given the } \\
\text { underlying societal trends toward } \\
\text { increasing use of most guideline- } \\
\text { recommended therapies, it is important } \\
\text { to examine the change in rate of } \\
\text { increase with any intervention } \\
\text { designed to improve care. }\end{array}$ \\
\hline $\begin{array}{l}\text { Cutshall et } \\
\text { al., } 2018 .\end{array}$ & $\begin{array}{l}\text { Level II } \\
\text { Grade B }\end{array}$ & $\begin{array}{l}\text { How effective is } \\
\text { the treatment of } \\
\text { HfrEF and its } \\
\text { outcomes in } \\
\text { patients with } \\
\text { ESRD requiring } \\
\text { dialysis in the } \\
\text { inpatient setting? }\end{array}$ & None & $\begin{array}{l}\text { Patients were identified } \\
\text { through the corporate } \\
\text { patient financial } \\
\text { services } \\
\text { database using ICD-9- } \\
\text { CM code } 586.6 \text { for } \\
\text { ESRD and } \\
\text { ICD-9-CM codes for } \\
\text { HfrEF. Patients were } \\
\text { included if } \\
\text { they were at least } 18 \\
\text { years of age, had a } \\
\text { diagnosis of } \\
\text { ESRD requiring } \\
\text { hemodialysis (HD) or } \\
\text { peritoneal dialysis } \\
\text { (PD), had a diagnosis } \\
\text { of HfrEF or had a } \\
\text { documented }\end{array}$ & $\begin{array}{l}\text { Patient demographics and } \\
\text { comorbidities were } \\
\text { collected for all patients. } \\
\text { Any HF med that was } \\
\text { administered to a patient } \\
\text { while hospitalized, as } \\
\text { documented in the } \\
\text { electronic medication } \\
\text { administration } \\
\text { record, was collected to } \\
\text { determine if patients } \\
\text { continued } \\
\text { or initiated HF } \\
\text { medications during } \\
\text { hospitalization. } \\
\text { Discharge medications } \\
\text { were also collected from } \\
\text { the discharge summary to } \\
\text { determine whether }\end{array}$ & $\begin{array}{l}\text { The study did not } \\
\text { show improved } \\
\text { short-term } \\
\text { outcomes, the } \\
\text { decrease of LOS in } \\
\text { the GDMT Current } \\
\text { guidelines } \\
\text { recommend standard } \\
\text { therapy for patients } \\
\text { with HfrEF and } \\
\text { ESRD these } \\
\text { guidelines are not } \\
\text { routinely being } \\
\text { followed. }\end{array}$ & $\begin{array}{l}\text { Investigations need to be made into } \\
\text { why ESRD and HfrEF patients are not } \\
\text { receiving GDMT. }\end{array}$ \\
\hline
\end{tabular}




\begin{tabular}{|c|c|c|c|c|c|c|c|}
\hline & & & & $\begin{array}{l}\text { ejection fraction of } \\
40 \% \text { within a year prior } \\
\text { to admission, and had a } \\
\text { hospital } \\
\text { length of stay (LOS) of } \\
\text { at least } 3 \text { days. Patients } \\
\text { were } \\
\text { excluded if they were } \\
\text { admitted directly to an } \\
\text { intensive } \\
\text { care unit, were } \\
\text { pregnant, had a history } \\
\text { of kidney } \\
\text { transplant, or were } \\
\text { diagnosed with ESRD } \\
\text { within } 3 \\
\text { months of admission. }\end{array}$ & $\begin{array}{l}\text { patients were prescribed } \\
\text { HF therapy at discharge. } \\
\text { Statistical tests used to } \\
\text { analyze baseline } \\
\text { characteristics and study } \\
\text { outcomes were the chi } \\
\text { square, Fisher's } \\
\text { exact test or Mann- } \\
\text { Whitney U test where } \\
\text { appropriate, by } \\
\text { means of the Minitab } \\
\text { statistical software. }\end{array}$ & & \\
\hline $\begin{array}{l}\text { Yamaguchi } \\
\text { et al., } 2018 .\end{array}$ & $\begin{array}{l}\text { Level II } \\
\text { Grade B }\end{array}$ & $\begin{array}{l}\text { What is the status } \\
\text { of GDMT at the } \\
\text { time of discharge } \\
\text { in patients } \\
\text { hospitalized with } \\
\text { acute HF and to } \\
\text { evaluate its } \\
\text { association with } \\
\text { all-cause } \\
\text { mortality and HF } \\
\text { readmission, } \\
\text { using real-world } \\
\text { multicenter } \\
\text { prospective } \\
\text { registry data? }\end{array}$ & None & $\begin{array}{l}1,682 \text { consecutive } \\
\text { patients hospitalized } \\
\text { with acute HF were } \\
\text { prospectively } \\
\text { registered from } 20 \\
\text { hospitals in Japan. } \\
\text { Excluded } 13 \text { patients } \\
\text { with in-hospital death } \\
\text { and nine patients with } \\
\text { missing data on GDMT } \\
\text { at discharge. }\end{array}$ & $\begin{array}{l}\text { All consecutive patients } \\
\text { aged } \geq 20 \text { years old with a } \\
\text { primary diagnosis of acute } \\
\text { HF hospitalized through } \\
\text { the emergency department } \\
\text { at participating hospitals } \\
\text { were enrolled upon the } \\
\text { initial hospital admission } \\
\text { and were followed-up. } \\
\text { Patient information at the } \\
\text { time of discharge and } \\
\text { prognosis within } 1 \text { year of } \\
\text { discharge was } \\
\text { prospectively collected. } \\
\text { Data were collected up to } \\
\text { December 2016. End } \\
\text { points of this study were } \\
\text { all-cause death and HF } \\
\text { readmission within one } \\
\text { year of discharge. Data } \\
\text { are expressed as mean and } \\
\text { standard deviation for } \\
\text { normally distributed } \\
\text { variables, and as median } \\
\text { with interquartile range } \\
\text { (IQR) for non-normally } \\
\text { distributed data. } \\
\text { Categorical data are } \\
\text { expressed as numbers and } \\
\text { percentages. The Kruskal- } \\
\text { Wallis test, chi-square } \\
\text { tests, Kaplan-Meier }\end{array}$ & $\begin{array}{l}\text { The prescription of } \\
\text { GDMT before } \\
\text { discharge was } \\
\text { significantly } \\
\text { associated with a } \\
\text { lower 1-year } \\
\text { mortality. Patients } \\
\text { on both ACE-I/ARB } \\
\text { and BB at discharge } \\
\text { showed more } \\
\text { favorable 1-year } \\
\text { survival than } \\
\text { patients on either } \\
\text { ACE-I/ARB or BB. } \\
\text { GDMT was not } \\
\text { associated with a } \\
\text { lower HF } \\
\text { readmission rate } \\
\text { when accounting for } \\
\text { death as a competing } \\
\text { risk }\end{array}$ & $\begin{array}{l}\text { Results imply that the hospitalization } \\
\text { is an important time to optimize HF } \\
\text { medication for patients with HF. }\end{array}$ \\
\hline
\end{tabular}




\begin{tabular}{|c|c|c|c|c|c|c|c|}
\hline & & & & & $\begin{array}{l}\text { estimates, log-rank test, } \\
\text { Gray test, the Cox } \\
\text { regression model, and the } \\
\text { Hosmer-Lemeshow test } \\
\text { were all used. Statistical } \\
\text { analyses were performed } \\
\text { using R version 3.1.2. }\end{array}$ & & \\
\hline $\begin{array}{l}\text { Fonarow et } \\
\text { al., } 2012 .\end{array}$ & $\begin{array}{l}\text { Level III } \\
\text { Grade A }\end{array}$ & $\begin{array}{l}\text { What are the } \\
\text { individual and } \\
\text { incremental } \\
\text { benefits of } \\
\text { guideline- } \\
\text { recommended } \\
\text { HF therapies } \\
\text { associated with } \\
\text { 24-month } \\
\text { survival? }\end{array}$ & None & $\begin{array}{l}\text { Patients with a clinical } \\
\text { diagnosis of HF or } \\
\text { prior myocardial } \\
\text { infarction documented } \\
\text { on at least } 2 \text { separate } \\
\text { visits were eligible for } \\
\text { enrollment. Reduced } \\
\text { LVEF was required to } \\
\text { be demonstrated by a } \\
\text { quantitative LVEF } \\
\leq 35 \% \text { or by qualitative } \\
\text { findings of moderate to } \\
\text { severe left ventricular } \\
\text { systolic dysfunction. } \\
\text { Patients with a non- } \\
\text { cardiovascular medical } \\
\text { condition with an } \\
\text { estimated survival of } \\
<1 \text { year and those who } \\
\text { had undergone cardiac } \\
\text { transplantation were } \\
\text { excluded. }\end{array}$ & $\begin{array}{l}\text { Data were collected by } \\
\text { medical chart review. A } \\
\text { logistic regression model } \\
\text { was used. Descriptive } \\
\text { summary statistics of } \\
\text { baseline patient and } \\
\text { practice characteristics } \\
\text { were calculated for the } \\
\text { case and control groups } \\
\text { and both groups } \\
\text { combined. Continuous } \\
\text { variables were analyzed } \\
\text { using the 2-sample t test, } \\
\text { and categorical variables } \\
\text { were analyzed with the } \\
\text { chi-square test. The } \\
\text { unadjusted odds ratio } \\
\text { (OR) of death was } \\
\text { determined using a } \\
\text { logistic regression model } \\
\text { with the therapy as the } \\
\text { predictor variable and no } \\
\text { covariate adjustment. } \\
\text { Analyses were completed } \\
\text { with SAS statistical } \\
\text { software, version } 9.1 \text {. }\end{array}$ & $\begin{array}{l}\text { Individual and } \\
\text { incremental use of } \\
\text { guideline- } \\
\text { recommended } \\
\text { therapies was } \\
\text { associated with } \\
\text { survival benefit, } \\
\text { with a potential } \\
\text { plateau at } 4 \text { to } 5 \\
\text { therapies. There was } \\
\text { an incremental } \\
\text { benefit with each } \\
\text { successive } \\
\text { guideline- } \\
\text { recommended } \\
\text { therapy. }\end{array}$ & $\begin{array}{l}\text { Provides further rationale to } \\
\text { implement guideline-recommended } \\
\text { HF therapies in the absence of } \\
\text { contraindications to patients with HF } \\
\text { and reduced left ventricular ejection } \\
\text { fraction. }\end{array}$ \\
\hline $\begin{array}{l}\text { Basoor et } \\
\text { al., } 2013 .\end{array}$ & $\begin{array}{l}\text { Level I } \\
\text { Grade A }\end{array}$ & $\begin{array}{l}\text { Is using a simple } \\
\text { checklist for HF } \\
\text { associated with } \\
\text { better quality of } \\
\text { care and } \\
\text { decreased } \\
\text { readmission for } \\
\text { HF patients? }\end{array}$ & None & $\begin{array}{l}\text { The selection of } \\
\text { patients for use of the } \\
\text { checklist was the } \\
\text { decision of the } \\
\text { attending physician or } \\
\text { house staff or nurse } \\
\text { practitioner taking care } \\
\text { of the patient and was } \\
\text { encouraged but not } \\
\text { enforced to be used for } \\
\text { all HF patients. } \\
\text { Inclusion criteria } \\
\text { included patients } \\
\text { admitted with a } \\
\text { primary diagnosis of }\end{array}$ & $\begin{array}{l}\text { Continuous variables are } \\
\text { presented as mean } \\
\text { standard deviation and } \\
\text { categorical variables as } \\
\text { frequencies and } \\
\text { percentages. Unpaired } \\
\text { Student t test was used to } \\
\text { compare continuous } \\
\text { variables. Test for two } \\
\text { proportions and chi- } \\
\text { square test were used to } \\
\text { compare categorical } \\
\text { variables. Fisher exact test } \\
\text { was used instead if any } \\
\text { one value in the }\end{array}$ & $\begin{array}{l}\text { The study } \\
\text { demonstrates a } \\
\text { decrease in 30-day } \\
\text { and 6-month } \\
\text { readmission rates for } \\
\text { HF patients with the } \\
\text { use of the checklist. }\end{array}$ & $\begin{array}{l}\text { Use of a checklist may have a } \\
\text { significant impact in enhancing quality } \\
\text { of care, improving clinical outcomes, } \\
\text { and, in turn, decreasing the burden on } \\
\text { the health care system. }\end{array}$ \\
\hline
\end{tabular}




\begin{tabular}{|c|c|c|c|c|c|c|c|}
\hline & & & & $\begin{array}{l}\text { acute decompensated } \\
\text { HF from August } 2008 \\
\text { to October } 2009 . \\
\text { Exclusion criteria } \\
\text { included pregnancy } \\
\text { and patients younger } \\
\text { than } 18 \text { years. }\end{array}$ & $\begin{array}{l}\text { calculation was }<5 . \\
\text { Statistical tests were } \\
\text { derived from Mini Tab } \\
\text { 15.3, version } 8 .\end{array}$ & & \\
\hline $\begin{array}{l}\text { Deschaseaux } \\
\text { et al., } 2016 .\end{array}$ & $\begin{array}{l}\text { Level III } \\
\text { Grade B }\end{array}$ & $\begin{array}{l}\text { What is the } \\
\text { treatment } \\
\text { initiation patterns } \\
\text { among newly } \\
\text { diagnosed HF } \\
\text { patients in the } \\
\text { United States, } \\
\text { subsequent } \\
\text { treatment } \\
\text { modifications, } \\
\text { hospitalizations } \\
\text { and the impact of } \\
\text { hospitalizations } \\
\text { on therapy } \\
\text { changes, and } \\
\text { treatment } \\
\text { adherence and } \\
\text { persistence? }\end{array}$ & None & $\begin{array}{l}\text { Data came from the } \\
\text { administrative claims } \\
\text { of the Truven Health } \\
\text { Market Scan } \\
\text { Commercial Claims } \\
\text { and Encounters } \\
\text { (CCAE) database and } \\
\text { the Medicare } \\
\text { Supplemental and } \\
\text { Coordination of } \\
\text { Benefits database. } \\
\text { Adult patients ( }>18 \\
\text { years of age) with at } \\
\text { least } 2 \text { medical claims } \\
\text { within } 12 \text { months on } \\
\text { different dates } \\
\text { corresponding to a HF } \\
\text { diagnosis during the } \\
\text { period from April } 1, \\
\text { 2009, to March } 31 \text {, } \\
\text { 2012, were identified. } \\
\text { Patients were required } \\
\text { to have continuous } \\
\text { enrollment in the } \\
\text { database for } 1 \text { year } \\
\text { before the diagnosis of } \\
\text { congestive HF and at } \\
\text { least } 1 \text { year of follow- } \\
\text { up data after the index } \\
\text { date. To ensure that } \\
\text { prevalent patients were } \\
\text { not included, patients } \\
\text { with HF diagnosis in } \\
\text { the } 12 \text { months pre- } \\
\text { index period were } \\
\text { excluded. Patients with } \\
\text { multiple comorbidities } \\
\text { were not excluded. }\end{array}$ & $\begin{array}{l}\text { Data were summarized } \\
\text { using descriptive } \\
\text { analyses. For categorical } \\
\text { variables, counts and } \\
\text { percentages were } \\
\text { provided for each } \\
\text { treatment class. No testing } \\
\text { information provided. }\end{array}$ & $\begin{array}{l}\text { More than one third } \\
\text { of newly diagnosed } \\
\text { HF patients do not } \\
\text { receive HF-specific } \\
\text { medication within } \\
30 \text { days following } \\
\text { initial diagnosis. } \\
\text { More than } 60 \% \text { of } \\
\text { patients continued } \\
\text { on the same therapy } \\
\text { after all-cause or } \\
\text { HF-related } \\
\text { hospitalization. }\end{array}$ & $\begin{array}{l}\text { We need to understand the reasons for } \\
\text { the demonstrated delay in HF } \\
\text { treatment initiation and limited use of } \\
\text { guideline-directed medical therapy } \\
\text { after initial diagnosis. }\end{array}$ \\
\hline
\end{tabular}




\section{Legend:}

AA- Aldosterone antagonist

ACEi/ARB- Angiotensin-converting enzyme inhibitors/Angiotensin II receptor blockers

AMI-Acute myocardial infarction

BB-Beta blocker

CMS-Centers for Medicare and Medicaid Services

ESRD-End-stage renal disease

HF-Heart failure

HfrEF-Heart failure with reduced ejection fraction

GDMT-Guideline directed medical therapy

GWTG- Get With The Guidelines

SAS-Statistical analysis software 


\section{Appendix D}

Table 1

\section{Synthesis Table}

\begin{tabular}{|c|c|c|c|c|c|}
\hline & \multicolumn{5}{|c|}{ Themes } \\
\hline Articles & $\begin{array}{c}\text { Variability in treatment of } \\
\text { HF patients }\end{array}$ & $\begin{array}{l}\text { Improvement of } \\
\text { mortality }\end{array}$ & Effect on readmission & $\begin{array}{c}\text { Renal dysfunction leading to } \\
\text { readmission }\end{array}$ & $\begin{array}{c}\text { Leadership involvement and further } \\
\text { research for performance and quality } \\
\text { improvement for HF. }\end{array}$ \\
\hline $\begin{array}{l}\text { Kociol et al., } \\
2012\end{array}$ & $\begin{array}{l}\text { Hospitals varied significantly } \\
\text { with processes of care used; } \\
\text { Use of computerized } \\
\text { reminders and discharge } \\
\text { checklists to improve } \\
\text { adherence to evidence-based } \\
\text { therapies used in }<50 \% \text { of } \\
\text { sites surveyed. }\end{array}$ & & $\begin{array}{l}\text { Only processes in the } \\
\text { discharge and } \\
\text { transitional care domain } \\
\text { had even a modest } \\
\text { association with lower } \\
\text { readmission rate. }\end{array}$ & . & $\begin{array}{l}\text { Results suggest a need for better evidence and } \\
\text { resources dedicated to effectively achieve } \\
\text { lower readmission rates. }\end{array}$ \\
\hline $\begin{array}{l}\text { Gilstrap et } \\
\text { al., } 2018\end{array}$ & $\begin{array}{l}\text { Clinicians frequently deviate } \\
\text { from guidelines at both } \\
\text { academic and community } \\
\text { hospitals }\end{array}$ & & & $\begin{array}{l}\text { Renal dysfunction was the } \\
\text { most common reason for } \\
\text { discharge with congestion, and } \\
\text { hypotension the most common } \\
\text { reason for discharge with no or } \\
\text { decreased neurohormonal } \\
\text { therapy. }\end{array}$ & \\
\hline $\begin{array}{l}\text { Bergethon et } \\
\text { al., } 2016\end{array}$ & & & $\begin{array}{l}\text { Teaching hospitals > } \\
\text { relative readmission rates } \\
\text { compared with } \\
\text { nonteaching hospitals; } \\
1.4 \% \text { of hospitals } \\
\text { examined in this study } \\
\text { achieved a } 20 \% \\
\text { reduction in relative } 30 \text { - } \\
\text { day readmission rates; } \\
\text { hospitals that used post } \\
\text { discharge heart failure } \\
\text { disease management } \\
\text { programs had lower } \\
\text { relative readmission } \\
\text { rates. }\end{array}$ & & \\
\hline
\end{tabular}




\begin{tabular}{|c|c|c|c|c|c|}
\hline $\begin{array}{l}\text { Wang et al., } \\
2011\end{array}$ & & $\begin{array}{l}\text { Hospitals with excellent } \\
\text { performance to both } \\
\text { AMI and HF processes } \\
\text { had significantly longer } \\
\text { duration of GWTG } \\
\text { participation and less in- } \\
\text { hospital mortality }\end{array}$ & & & \\
\hline $\begin{array}{l}\text { Heidenreich } \\
\text { et al., } 2014\end{array}$ & $\begin{array}{l}\text { The use of several treatments } \\
\text { remained low, including use } \\
\text { of hydralazine-nitrate } \\
\text { combination for patients of } \\
\text { African descent and } \\
\text { aldosterone antagonists in } \\
\text { appropriate candidates. }\end{array}$ & & & & $\begin{array}{l}\text { Public reporting of hospital quality may have } \\
\text { a greater impact than recognition of top } \\
\text { hospitals because of stigma. Joint } \\
\text { Commission and CMS have measured and } \\
\text { publicly reported hospital quality of care for } \\
\text { more than } 10 \text { years. }\end{array}$ \\
\hline $\begin{array}{l}\text { Cutshall et } \\
\text { al., } 2018\end{array}$ & $\begin{array}{l}\text { Most patients with ESRD and } \\
\text { HfrEF were not receiving } \\
\text { GDMT }\end{array}$ & & $\begin{array}{l}\text { Shorter LOS in the } \\
\text { GDMT group may be } \\
\text { clinically significant }\end{array}$ & $\begin{array}{l}\text { Carvedilol remains a preferred } \\
\text { agent in this } \\
\text { patient population, which was } \\
\text { also observed in our study } \\
\text { based on the prescribed home } \\
\text { medications. }\end{array}$ & \\
\hline $\begin{array}{l}\text { Yamaguchi } \\
\text { et al., } 2018\end{array}$ & $\begin{array}{l}83.7 \% \text { of patients receiving } \\
\text { BB at discharge, whereas } \\
72.5 \% \text { of patients receiving } \\
\text { ACE-I/ARB at discharge }\end{array}$ & $\begin{array}{l}\text { Optimization of GDMT } \\
\text { before discharge was } \\
\text { associated with a lower } \\
\text { 1-year mortality in } \\
\text { patients hospitalized with } \\
\text { HfrEF }\end{array}$ & & & \\
\hline $\begin{array}{l}\text { Fonarow et } \\
\text { al., } 2012\end{array}$ & & $\begin{array}{l}\text { Strong associations } \\
\text { between } \beta \text {-blocker and } \\
\text { ACEI/ARB use and } \\
\text { improved survival. } \\
\text { Individual, and } \\
\text { incremental use of } \\
\text { GDMT therapies was } \\
\text { associated with survival } \\
\text { benefit }\end{array}$ & & & $\begin{array}{l}\text { Data may provide further rationale for using } \\
\text { systems, performance improvement, and } \\
\text { disease management programs to ensure the } \\
\text { implementation of guideline-recommended } \\
\text { HF therapies into clinical practice. }\end{array}$ \\
\hline
\end{tabular}




\begin{tabular}{|c|c|c|c|c|}
\hline $\begin{array}{l}\text { Basoor et } \\
\text { al., } 2013\end{array}$ & $\begin{array}{l}\text { Use of the HF checklist } \\
\text { resulted in increased use of } \\
\text { ACE inhibitors/ARBs at } \\
\text { discharge. }\end{array}$ & $\begin{array}{l}\text { This checklist may have } \\
\text { a significant impact in } \\
\text { enhancing quality of } \\
\text { care, improving clinical } \\
\text { outcomes, and, in turn, } \\
\text { decreasing the burden on } \\
\text { the health care system }\end{array}$ & $\begin{array}{l}\text { The use of an HF } \\
\text { checklist was associated } \\
\text { with better quality of } \\
\text { care and decreased } \\
\text { readmission rates for } \\
\text { patients admitted with } \\
\text { HF }\end{array}$ & $\begin{array}{l}\text { Large-scale quality-improvement projects are } \\
\text { needed to further validate the effects of a HF } \\
\text { checklist }\end{array}$ \\
\hline $\begin{array}{l}\text { Deschaseaux } \\
\text { et al., } 2016\end{array}$ & $\begin{array}{l}\text { Approximately } 42 \% \text { of } \\
\text { patients not prescribed HF- } \\
\text { specific treatment within } 30 \\
\text { days } .1 / 3 \text { of newly diagnosed } \\
\text { HF patients do not receive } \\
\text { HF-specific medication } \\
\text { within } 30 \text { days following } \\
\text { initial diagnosis. }\end{array}$ & & & $\begin{array}{l}\text { Need for further research to better understand } \\
\text { the reasons for the demonstrated delay in HF } \\
\text { treatment initiation and limited use of } \\
\text { guideline-directed medical therapy after initial } \\
\text { diagnosis. }\end{array}$ \\
\hline
\end{tabular}


Appendix E

Table 1

\section{Project Schedule}

\begin{tabular}{|c|c|c|c|c|c|c|c|c|c|c|c|c|c|c|c|c|c|c|c|c|c|c|c|c|}
\hline & \multicolumn{8}{|c|}{ NUR7801 } & \multicolumn{8}{|c|}{ NUR7802 } & \multicolumn{8}{|c|}{ NUR7803 } \\
\hline 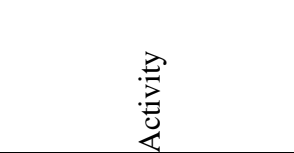 & $\begin{array}{l}\bar{y} \\
\frac{\pi}{2} \\
3\end{array}$ & $\begin{array}{l}m \\
\frac{m}{2} \\
3 \\
3\end{array}$ & $\begin{array}{l}n \\
\frac{1}{8} \\
\sum^{0}\end{array}$ & $\frac{\pi}{8}$ & $\begin{array}{l}a \\
\frac{y}{0} \\
3 \\
3\end{array}$ & $\begin{array}{l}= \\
\frac{1}{0} \\
\frac{d}{3}\end{array}$ & $\begin{array}{l}\frac{m}{2} \\
\frac{1}{0} \\
\frac{d}{3}\end{array}$ & $\begin{array}{l}n \\
\frac{n}{0} \\
\frac{0}{0} \\
3\end{array}$ & $\begin{array}{l}7 \\
\frac{\pi}{2} \\
3 \\
3\end{array}$ & $\begin{array}{l}m \\
\frac{y}{d} \\
\frac{d}{3}\end{array}$ & $\begin{array}{l}n \\
\frac{y}{0} \\
3 \\
3\end{array}$ & $\begin{array}{l}5 \\
\frac{y}{d} \\
3\end{array}$ & $\begin{array}{l}a \\
\frac{y}{d} \\
3 \\
3\end{array}$ & $\begin{array}{l}= \\
\frac{1}{0} \\
\frac{d}{3} \\
3\end{array}$ & $\begin{array}{l}\frac{m}{y} \\
\frac{\pi}{0} \\
3\end{array}$ & $\begin{array}{l}\frac{n}{\pi} \\
\frac{n}{0} \\
3\end{array}$ & $\frac{7}{8}$ & $\begin{array}{l}m \\
\frac{n}{8} \\
\frac{d}{3}\end{array}$ & $\begin{array}{l}n \\
\frac{y}{8} \\
\sum^{\infty}\end{array}$ & $\frac{1}{8}$ & $\begin{array}{l}\frac{a}{8} \\
\frac{0}{0} \\
3\end{array}$ & $\begin{array}{l}= \\
\frac{1}{10} \\
\frac{0}{3}\end{array}$ & $\begin{array}{l}\frac{m}{4} \\
\frac{1}{0} \\
\frac{0}{3}\end{array}$ & $\begin{array}{l}n \\
\frac{n}{2} \\
\frac{0}{3} \\
3\end{array}$ \\
\hline $\begin{array}{l}\text { ID practice problem, } \\
\text { review literature, and } \\
\text { appraise. }\end{array}$ & & & & & & & & & & & & & & & & & & & & & & & & \\
\hline $\begin{array}{l}\text { Review prospective } \\
\text { project plan and literature } \\
\text { results with preceptor and } \\
\text { Update supportive } \\
\text { evidence table }\end{array}$ & & & & & & & & & & & & & & & & & & & & & & & & \\
\hline $\begin{array}{l}\text { ID Key stakeholders and } \\
\text { team members with } \\
\text { preceptor }\end{array}$ & & & & & & & & & & & & & & & & & & & & & & & & \\
\hline $\begin{array}{l}\text { Speak with key } \\
\text { stakeholders and obtain } \\
\text { executive support }\end{array}$ & & & & & & & & & & & & & & & & & & & & & & & & \\
\hline $\begin{array}{l}\text { ID action plan, potential } \\
\text { budget, and prospective } \\
\text { time line with preceptor. } \\
\text { Review evaluation and } \\
\text { dissemination plan. }\end{array}$ & & & & & & & & & & & & & & & & & & & & & & & & \\
\hline $\begin{array}{l}\text { Complete IHI } \\
\text { Improvement Capability } \\
\text { Self-Assessment Tool } \\
\text { and identify and discuss } \\
\text { gap for needed } \\
\text { organizational process } \\
\text { change }\end{array}$ & & & & & & & & & & & & & & & & & & & & & & & & \\
\hline $\begin{array}{l}\text { ID possible limitations, } \\
\text { goals and milestones with } \\
\text { preceptor. Identify HER } \\
\text { capability for project } \\
\text { timeline. }\end{array}$ & & & & & & & & & & & & & & & & & & & & & & & & \\
\hline Finalize project proposal & & & & & & & & & & & & & & & & & & & & & & & & \\
\hline $\begin{array}{l}\text { Examine IRB protocols } \\
\text { with preceptor }\end{array}$ & & & & & & & & & & & & & & & & & & & & & & & & \\
\hline $\begin{array}{l}\text { ID Metrics from the } \\
\text { measures identified from } \\
\text { the internal data and set }\end{array}$ & & & & & & & & & & & & & & & & & & & & & & & & \\
\hline
\end{tabular}




\begin{tabular}{|c|c|c|c|c|c|c|c|c|c|c|c|c|c|c|c|c|c|c|c|c|c|c|c|c|}
\hline & \multicolumn{8}{|c|}{ NUR7801 } & \multicolumn{8}{|c|}{ NUR7802 } & \multicolumn{8}{|c|}{ NUR7803 } \\
\hline 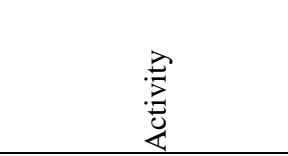 & $\begin{array}{l}\bar{y} \\
\frac{\pi}{0} \\
3\end{array}$ & $\frac{m}{\frac{n}{0}}$ & $\frac{n}{8}$ & $\frac{5}{3}$ & $\begin{array}{l}\frac{9}{0} \\
\frac{u}{3} \\
3\end{array}$ & $\begin{array}{l}= \\
\frac{y}{2} \\
\frac{d}{3}\end{array}$ & $\begin{array}{l}\frac{m}{2} \\
\frac{1}{0} \\
\frac{d}{3}\end{array}$ & $\begin{array}{l}n \\
\frac{1}{2} \\
\frac{1}{3}\end{array}$ & $\frac{\sqrt{4}}{3}$ & $\frac{m}{\frac{y}{d}}$ & $\begin{array}{l}n \\
\frac{y}{0} \\
\frac{d}{3}\end{array}$ & $\frac{\bar{y}}{\frac{y}{d}}$ & $\begin{array}{l}a \\
\frac{y}{d} \\
z\end{array}$ & $\begin{array}{l}= \\
\frac{1}{0} \\
3\end{array}$ & $\frac{m}{\frac{y}{d}}$ & $\frac{n}{\frac{n}{d}}$ & $\frac{\bar{x}}{\bar{d}}$ & $\begin{array}{l}\frac{m}{2} \\
\frac{0}{3} \\
3\end{array}$ & $\begin{array}{l}n \\
\frac{1}{0} \\
3 \\
3\end{array}$ & $\frac{\bar{y}}{3}$ & $\begin{array}{l}a \\
\frac{1}{0} \\
\frac{0}{3}\end{array}$ & $\begin{array}{l}= \\
\frac{y}{d} \\
\frac{d}{3}\end{array}$ & $\begin{array}{l}\frac{m}{4} \\
\frac{y}{d} \\
\frac{\pi}{3}\end{array}$ & $\frac{n}{\frac{n}{d}}$ \\
\hline performance measures & & & & & & & & & & & & & & & & & & & & & & & & \\
\hline Create Project Charter & & & & & & & & & & & & & & & & & & & & & & & & \\
\hline $\begin{array}{l}\text { Create Project Scope } \\
\text { Statement }\end{array}$ & & & & & & & & & & & & & & & & & & & & & & & & \\
\hline $\begin{array}{l}\text { Review Charter and } \\
\text { Scope Statement with } \\
\text { preceptor }\end{array}$ & & & & & & & & & & & & & & & & & & & & & & & & \\
\hline $\begin{array}{l}\text { Send invites to initial } \\
\text { meeting with key } \\
\text { stakeholders and plan } \\
\text { agenda with presentation } \\
\text { materials. }\end{array}$ & & & & & & & & & & & & & & & & & & & & & & & & \\
\hline $\begin{array}{l}\text { Present Project to } \\
\text { Stakeholders, confirm } \\
\text { budget, discuss project } \\
\text { plan, and participate in } \\
\text { the Failure Modes and } \\
\text { Effect Analysis (FMEA) } \\
\text { and assess for project } \\
\text { sustainability }\end{array}$ & & & & & & & & & & & & & & & & & & & & & & & & \\
\hline $\begin{array}{l}\text { Educate CVU staff on } \\
\text { discharge protocol } \\
\text { process and potential } \\
\text { benefits to patient } \\
\text { outcomes. }\end{array}$ & & & & & & & & & & & & & & & & & & & & & & & & \\
\hline $\begin{array}{l}\text { Initiate protocol on } \\
\text { inpatient unit }\end{array}$ & & & & & & & & & & & & & & & & & & & & & & & & \\
\hline $\begin{array}{l}\text { Evaluate adherence to } \\
\text { protocol, project data and } \\
\text { enter into evaluation } \\
\text { software. }\end{array}$ & & & & & & & & & & & & & & & & & & & & & & & & \\
\hline $\begin{array}{l}\text { Update key stakeholders } \\
\text { on progress of project }\end{array}$ & & & & & & & & & & & & & & & & & & & & & & & & \\
\hline $\begin{array}{l}\text { Collect project data and } \\
\text { enter into evaluation } \\
\text { software }\end{array}$ & & & & & & & & & & & & & & & & & & & & & & & & \\
\hline $\begin{array}{l}\text { Meet with Director of IS } \\
\text { to ensure correct data } \\
\text { evaluation methods. }\end{array}$ & & & & & & & & & & & & & & & & & & & & & & & & \\
\hline $\begin{array}{l}\text { Finalize project data } \\
\text { collection period and } \\
\text { enter all data. Begin } \\
\text { scholarly project report. }\end{array}$ & & & & & & & & & & & & & & & & & & & & & & & & \\
\hline $\begin{array}{l}\text { Conduct statistical } \\
\text { analysis to evaluate } \\
\text { reliability and feasibility } \\
\text { of results. }\end{array}$ & & & & & & & & & & & & & & & & & & & & & & & & \\
\hline
\end{tabular}




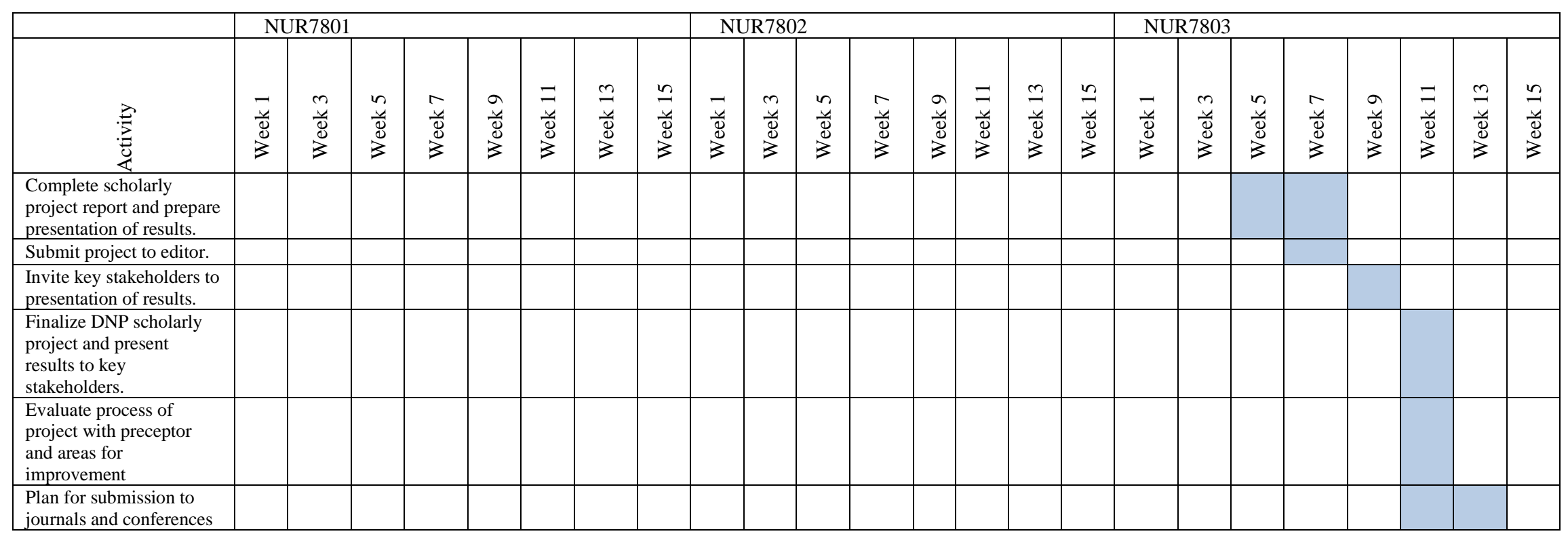




\section{Appendix F}

\section{Figure 1}

S.W.O.T Analysis

\begin{tabular}{|c|c|c|c|}
\hline $\begin{array}{c}\text { Strengths } \\
\text { (Internal positive) }\end{array}$ & $\begin{array}{c}\text { Weaknesses } \\
\text { (Internal negative) }\end{array}$ & $\begin{array}{c}\text { Opportunities } \\
\text { (External positive) }\end{array}$ & $\begin{array}{c}\text { Threats } \\
\text { (External negative) }\end{array}$ \\
\hline $\begin{array}{l}\text { - Experienced } \\
\text { leadership open to } \\
\text { EBP innovations } \\
\text { - Designated HF ARNP } \\
\text { dedicated to HF } \\
\text { patient outcome } \\
\text { improvement } \\
\text { - More financial } \\
\text { opportunity due to } \\
\text { large system } \\
\text { - Documented } \\
\text { evidence of HF 30- } \\
\text { day readmission } \\
\text { increase }\end{array}$ & $\begin{array}{l}\text { - Lack of established } \\
\text { relationship with } \\
\text { hospital leadership } \\
\text { - Recent financial } \\
\text { losses due to Covid- } \\
19 \\
\text { - Non-cardiologist } \\
\text { discharging HF } \\
\text { patients } \\
\text { - Lead investigator } \\
\text { must rely on } \\
\text { preceptor for } \\
\text { information } \\
\text { - Physician non- } \\
\text { compliance with } \\
\text { GDT } \\
\text { - Poor HF patient } \\
\text { education practices } \\
\text { at discharge }\end{array}$ & $\begin{array}{l}\text { - Lead investigator a } \\
\text { non-paid worker on } \\
\text { project } \\
\text { - Dedicated regional } \\
\text { director of AHA who } \\
\text { can provide student } \\
\text { support } \\
\text { - Underserved patient } \\
\text { diagnosis } \\
\text { - Established } \\
\text { relationship with } \\
\text { GWTG program and } \\
\text { award recipient } \\
\text { - Medication } \\
\text { assistance programs }\end{array}$ & $\begin{array}{l}\text { - Rising rates of Covid-19 } \\
\text { - Inability of student to } \\
\text { visit hospital campus } \\
\text { - History of HF patient } \\
\text { non-compliance } \\
\text { - Limitations of study } \\
\text { timing } \\
\text { - Personal obligations } \\
\text { outside of project } \\
\text { - Patients have difficulty } \\
\text { affording their } \\
\text { medication }\end{array}$ \\
\hline
\end{tabular}




\section{Appendix G}

\section{Table 1}

\section{Benchmarking Measures Data}

\begin{tabular}{|c|c|c|c|c|c|c|c|c|c|c|c|c|c|c|c|c|c|c|c|}
\hline Objective & Initiative & Measure & Target & Responsible & Reporting & Benchmark & \multicolumn{13}{|c|}{ Results } \\
\hline Outcome & $\begin{array}{l}\text { Reduce 30-day } \\
\text { readmission } \\
\text { rates of patients } \\
\text { with HF } \\
\end{array}$ & $\begin{array}{l}\text { 30-day } \\
\text { readmission } \\
\text { rate }\end{array}$ & $\begin{array}{l}\geq 20 \% \\
\text { reduction }\end{array}$ & Project manager & $\begin{array}{l}\text { Every } 30 \\
\text { days after } \\
\text { project start }\end{array}$ & $45 \%$ & \multicolumn{4}{|c|}{30 days } & \multicolumn{5}{|c|}{60 days } & \multicolumn{4}{|c|}{90 days } \\
\hline Process & $\begin{array}{l}\text { HF Discharge } \\
\text { protocol } \\
\text { utilization }\end{array}$ & $\begin{array}{l}\text { How many } \\
\text { times protocol } \\
\text { used/How } \\
\text { many HF } \\
\text { patients } \\
\text { discharged } \\
\end{array}$ & $\geq 95 \%$ & Project manager & Every week & $33 \%$ & 1 & 2 & 3 & 4 & 5 & 6 & 7 & 8 & 9 & 10 & 11 & 12 & 13 \\
\hline \multirow[t]{2}{*}{ Balancing } & \multirow{2}{*}{$\begin{array}{l}\text { Having charge } \\
\text { nurse identify } \\
\text { HF patients and } \\
\text { remind } \\
\text { practitioner in } \\
\text { daily rounding } \\
\text { about ordering } \\
\text { protocol at } \\
\text { discharge }\end{array}$} & $\begin{array}{l}\text { How many HF } \\
\text { patients were } \\
\text { identified? }\end{array}$ & $\begin{array}{l}\geq 95 \% \\
\text { of } \mathrm{HF} \\
\text { patients }\end{array}$ & Project manager & $\begin{array}{l}\text { Every } 2 \\
\text { weeks }\end{array}$ & 20 & \multicolumn{3}{|c|}{$1^{\text {st }} 2$ weeks } & \multicolumn{4}{|c|}{$2^{\text {nd }} 2$ weeks } & \multicolumn{3}{|c|}{$3^{\text {rd }} 2$ weeks } & \multicolumn{3}{|c|}{$4^{\text {th }} 2$ weeks } \\
\hline & & $\begin{array}{l}\text { How many } \\
\text { times did they } \\
\text { mention } \\
\text { protocol in } \\
\text { rounding? }\end{array}$ & $\geq 100 \%$ & Project manager & $\begin{array}{l}\text { Every } 2 \\
\text { weeks }\end{array}$ & 0 & \multicolumn{3}{|c|}{$1^{\text {st }} 2$ weeks } & \multicolumn{4}{|c|}{$2^{\text {nd }} 2$ weeks } & \multicolumn{3}{|c|}{$3^{\text {rd }} 2$ weeks } & \multicolumn{3}{|c|}{$4^{\text {th }} 2$ weeks } \\
\hline Financial & $\begin{array}{l}\text { Reduce } \\
\text { readmission } \\
\text { cost for HF } \\
\text { patients } \\
\end{array}$ & $\begin{array}{l}\text { Cost of } \\
\text { readmission }\end{array}$ & $\begin{array}{l}\geq 20 \% \\
\text { reduction }\end{array}$ & Project manager & $\begin{array}{l}\text { Every } 30 \\
\text { days after } \\
\text { project start }\end{array}$ & $\$ 146,310.00$ & \multicolumn{4}{|c|}{30 days } & \multicolumn{5}{|c|}{60 days } & \multicolumn{4}{|c|}{90 days } \\
\hline Sustainability & $\begin{array}{l}\text { HF Discharge } \\
\text { protocol } \\
\text { utilization post } \\
\text { project } \\
\text { conclusion }\end{array}$ & $\begin{array}{l}\text { How many } \\
\text { times protocol } \\
\text { used/How } \\
\text { many HF } \\
\text { patients } \\
\text { discharged } \\
\end{array}$ & $\begin{array}{l}\geq 95 \% \\
\text { utilization }\end{array}$ & Project manager & Once & $33 \%$ & \multicolumn{13}{|c|}{30 days post project completion date } \\
\hline
\end{tabular}




\section{Appendix H}

Table H1.

Frequencies for 30-day Readmission Rate

\begin{tabular}{lrrr}
\hline Variable & Pre & Post & Post-Post \\
\hline X30_Day_Readmission & & & \\
N & $25(71 \%)$ & $10(59 \%)$ & $14(74 \%)$ \\
Y & $10(29 \%)$ & $7(41 \%)$ & $5(26 \%)$ \\
Missing & $0(0 \%)$ & $0(0 \%)$ & $0(0 \%)$ \\
\hline Note. Due to rounding errors, column wise percentages may not equal $100 \%$.
\end{tabular}

\section{Table H2.}

Chi-square Test

\begin{tabular}{lrrrrr}
\hline & \multicolumn{3}{c}{ X30_Day_Readmission } & & \\
\cline { 2 - 5 } Phase & $\mathrm{N}$ & $\mathrm{Y}$ & $\chi^{2}$ & $d f$ & $p$ \\
\hline Pre & $25[24.15]$ & $10[10.85]$ & 1.11 & 2 & .573 \\
Post & $10[11.73]$ & $7[5.27]$ & & & \\
Post-Post & $14[13.11]$ & $5[5.89]$ & & & \\
\hline
\end{tabular}

Note. Values formatted as Observed[Expected].

\section{Table H3.}

Two-Tailed Paired Samples t-Test

\begin{tabular}{ccccccc}
\hline How_Many_X_Protocol_Used & \multicolumn{2}{l}{ How_Many_Pt_s_D_C_d } & & & \\
\cline { 1 - 3 } & $S D$ & $M$ & $S D$ & $t$ & $p$ & $d$ \\
\hline 1.46 & 1.71 & 5.46 & 3.45 & -6.68 & $<.001$ & 1.85 \\
\hline
\end{tabular}

Note. $\mathrm{N}=13$. Degrees of Freedom for the $t$-statistic $=12 . d$ represents Cohen's $d$. 
Table H4.

Process Measure

\begin{tabular}{|c|c|c|c|}
\hline Week & $\begin{array}{c}\text { How Many X Protocol } \\
\text { Used }\end{array}$ & How Many Pt's D/C'd & $\begin{array}{l}\text { \% of HF Discharge } \\
\text { Protocol Utilization }\end{array}$ \\
\hline 1 & 2 & $\overline{6}$ & $33 \%$ \\
\hline 2 & 6 & 14 & $43 \%$ \\
\hline 3 & 2 & 6 & $33 \%$ \\
\hline 4 & 0 & 7 & $0 \%$ \\
\hline 5 & 2 & 6 & $33 \%$ \\
\hline 6 & 1 & 6 & $17 \%$ \\
\hline 7 & 0 & 2 & $0 \%$ \\
\hline 8 & 2 & 3 & $67 \%$ \\
\hline 9 & 0 & 2 & $0 \%$ \\
\hline 10 & 0 & 2 & $0 \%$ \\
\hline 11 & 1 & 6 & $17 \%$ \\
\hline 12 & 0 & 2 & $0 \%$ \\
\hline 13 & 3 & 9 & $33 \%$ \\
\hline
\end{tabular}


Figure H1.

Run Chart of How Many Time Protocol Was Used

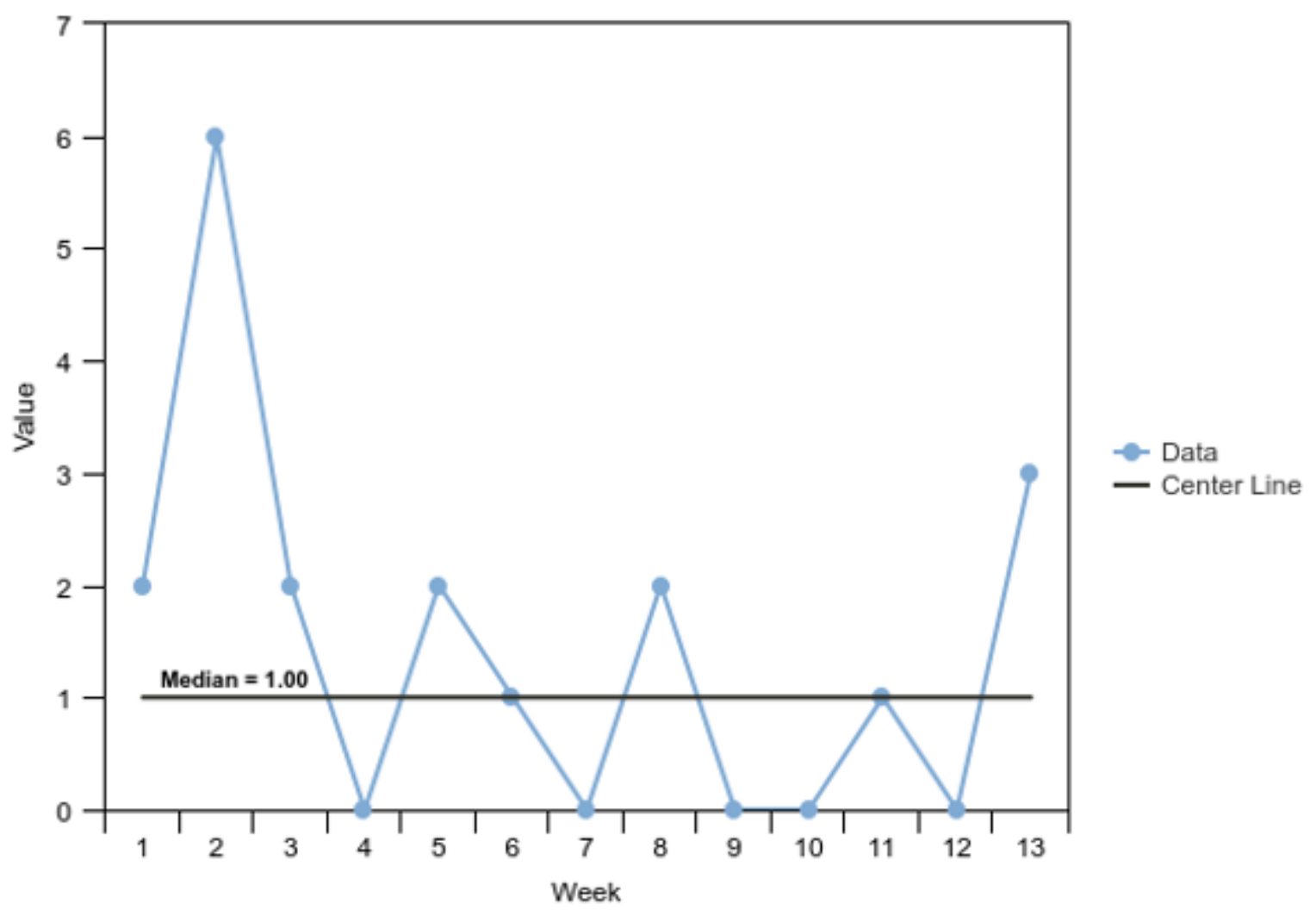




\section{Table H5.}

Number of Times Protocol Mentioned in Rounding to Physicians

\begin{tabular}{lrr}
\hline Variable & N & Y \\
\hline X2_week_interval & $19(58 \%)$ & $2(11 \%)$ \\
1 & $12(36 \%)$ & $0(0 \%)$ \\
2 & $2(6 \%)$ & $11(58 \%)$ \\
3 & $0(0 \%)$ & $6(32 \%)$ \\
4 & $0(0 \%)$ & $0(0 \%)$ \\
5 & $0(0 \%)$ & $0(0 \%)$ \\
Missing &
\end{tabular}

Table H6.

Financial Measure

\begin{tabular}{cccc}
\hline Time & $\begin{array}{c}\text { 30 Days } \\
\text { 9/15-10/14 }\end{array}$ & $\begin{array}{c}\text { 60 Days } \\
\mathbf{1 0 / 1 5 - 1 1 / 1 4}\end{array}$ & $\begin{array}{c}\text { 90 Days } \\
\mathbf{1 1 / 1 5 - 1 2 / 1 4}\end{array}$ \\
\hline Cost of Readmission & $\$ 146,310.00$ & $\$ 102,417.00$ & $\$ 73,155.00$ \\
\hline \# of Readmissions & 10 & 7 & 5 \\
\hline $\begin{array}{l}\text { Percent Reducation } \\
\text { Between Periods }\end{array}$ & $30 \%$ & & $29 \%$ \\
\hline
\end{tabular}


Figure H2.

Bar Plot of Protocol Usage in Trimester 3

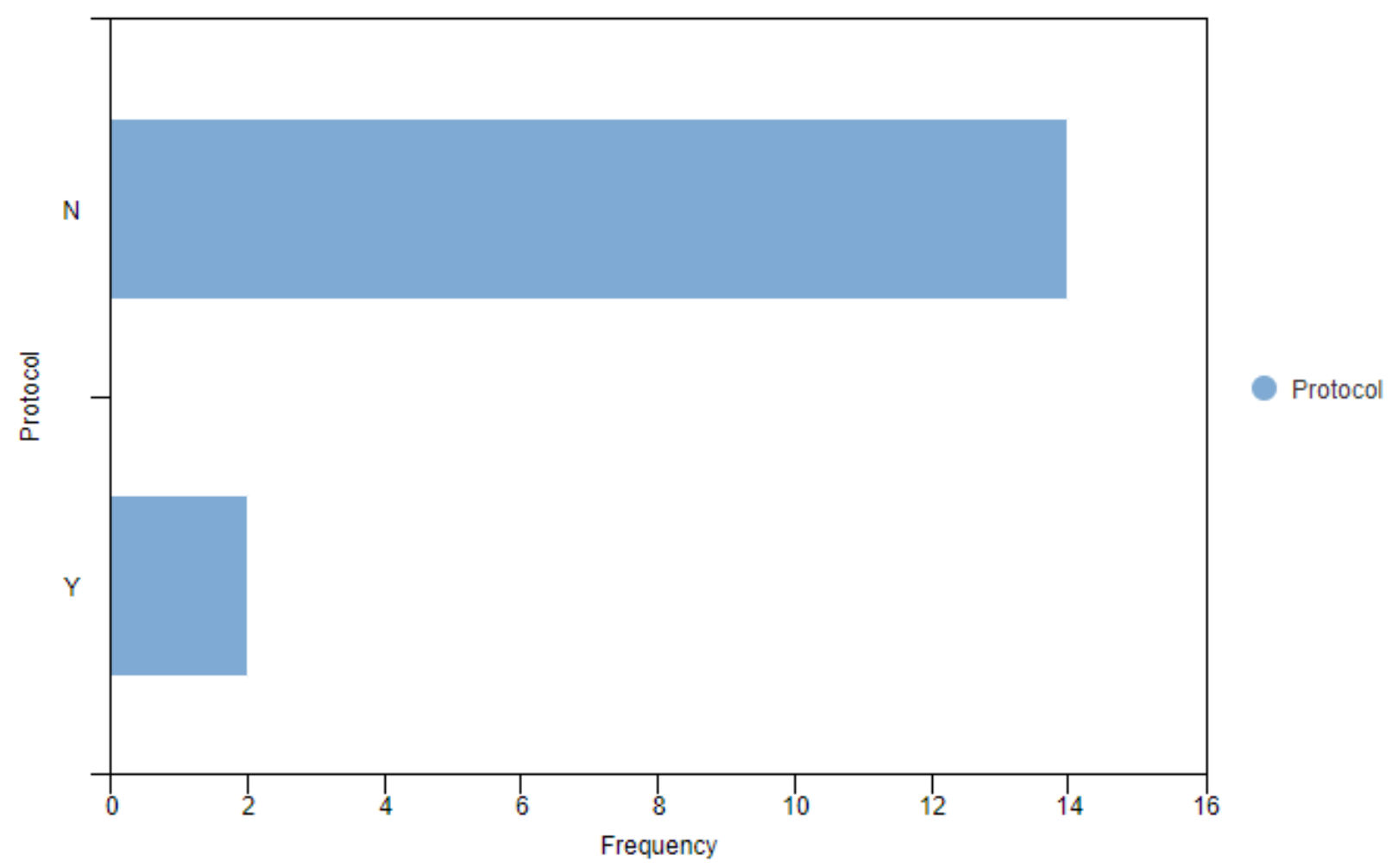




\title{
Appendix I
}

\section{Figure I1.}

\section{Approval email to use Iowa Model}

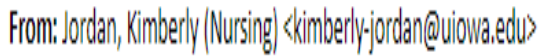

Sent: Thurscldy, July 16, 20209:24 AM

To: Dawn H Onstott 《donstott(Qusa,edu>

Subject: RE', [External)] Permission to use lowa Model

Dawn - apologies for not getting back to you yesterday.

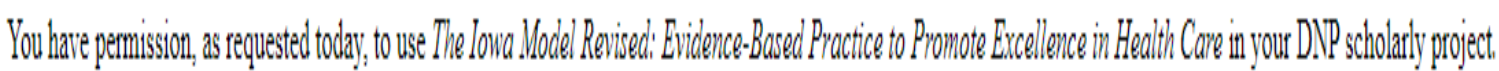

Copyright is rettaned by Cuniressity of lowa Hospitals and Clinics. Permission is not granted for placing on the internet.

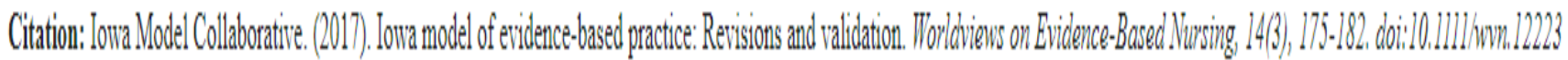
In witten material, please add the following statement:

Used reprinted with permission from the University of lowa Hospitals and Clinics, copvyight 2015 . For permission to use or regroduce, please contact the University of lova Hospitals and Cinics at 319.384.9098

Please feel free to contact if you have any questions.

\author{
Kim Jordan, AA

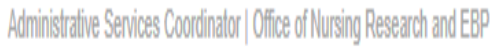 \\ Depatment ó N Wusing Services and Patient Care \\ Unversity of lowa Heath Care \\ 200 Hawkins Dine, T100 GH | IOwa City, IA52242 \\ Phone:319:3849998| Frax 319:356-4348

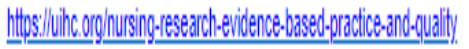




\section{Figure I2.}

Approval to Use Johns Hopkins Nursing Evidence-Based Practice Model and Tools

\begin{tabular}{|c|c|c|c|c|c|}
\hline \multicolumn{2}{|c|}{ \$ $\mathrm{JOHNS}$ HOPKINS } & & & \multicolumn{2}{|l|}{ Find a course... } \\
\hline & & & & & \\
\hline LEARNING SYSTEM HOME & COURSE CATALOG & CONTACT US & JOIN OUR MAILING LIST & IJHN WEBSITE & \\
\hline
\end{tabular}

Home " JHNEBP Model and Tools- Permission

\section{JHNEBP MODEL AND TOOLS- PERMISSION}

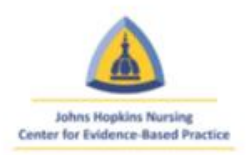

Thank you for your submission. We are happy to give you permission to use the JHNEBP model and tools in adherence of our legal terms noted below:

- You may not modify the model or the tools without written approval from Johns Hopkins.

- All reference to source forms should include "(The Johns Hopkins Hospital/The Johns Hopkins University."

- The tools may not be used for commercial purposes without special permission.

If interested in commercial use or discussing changes to the tool, please email ijhn@jhmi.edu.

Downloads:

JHNEBP Tools-Printable Version

JHNEBP Tools-Electronic Version

Do you prefer hands-on learning?

We are offering a 5-day intensive Boot Camp where you will learn and master the entire EBP process from beginning to end. Take advantage of our retreat-type setting to focus on your project, collaborate with peers, and get the expertise and assistance from our faculty. Click HERE to learn more about EBP Boot Camp. Group rates available, email jihn@jhmi.edu to inquire.

Go back to the form

Institute for Johns Hopkins Nursing

http://www.hopkinsmedicine.org/institute_nursing/

IJHN@jhmi.edu

443-287-4745 


\section{Figure I3.}

Letter of Approval from American Heart Association

Dianne Foster <Dianne.Foster@heart.org>

Thu 10/1/2020 1:39 PM

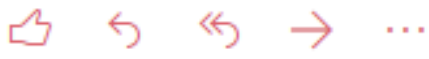

To: Dawn H Onstott

Cc: Sheri Jacobson

$\square$ RE: GWTG-HF Approval of Use

$925 \mathrm{~KB}$

Good afternoon,

As an addendum to my attached email, to clarify, Dawn Onstott has permission to reference the American Heart Association Get With The Guidelines ${ }^{\odot}$ Heart Failure discharge medication guidelines in her DNP Scholarly Project as required by the University of St. Augustine for Health Sciences Nursing Program.

Regards,

Dianne

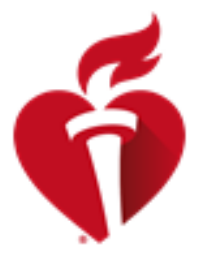

Dianne Foster, BSN, MBA

Regional Director, Quality Improvement

Quality, Outcomes Research \& Analytics

American Heart Association

O 678.224 .2042 | M 770.362 .9193 